\title{
Review \\ A Review on Synthesis Methods of Phyllosilicate- and Graphene-Filled Composite Hydrogels
}

\author{
Sayan Ganguly *(i) and Shlomo Margel *(i)
}

Bar-Ilan Institute for Nanotechnology and Advanced Materials, Department of Chemistry, Bar-Ilan University, Ramat-Gan 52900, Israel

* Correspondence: sayanganguly2206@gmail.com (S.G.); Shlomo.margel@biu.ac.il (S.M.)

check for updates

Citation: Ganguly, S.; Margel, S. A Review on Synthesis Methods of Phyllosilicate- and Graphene-Filled Composite Hydrogels. J. Compos. Sci. 2022, 6, 15. https://doi.org/ $10.3390 /$ jcs6010015

Academic Editor:

Francesco Tornabene

Received: 23 November 2021

Accepted: 30 December 2021

Published: 1 January 2022

Publisher's Note: MDPI stays neutral with regard to jurisdictional claims in published maps and institutional affiliations.

Copyright: (C) 2022 by the authors. Licensee MDPI, Basel, Switzerland. This article is an open access article distributed under the terms and conditions of the Creative Commons Attribution (CC BY) license (https:// creativecommons.org/licenses/by/ $4.0 /)$.

\begin{abstract}
This review discusses, in brief, the various synthetic methods of two widely-used nanofillers; phyllosilicate and graphene. Both are 2D fillers introduced into hydrogel matrices to achieve mechanical robustness and water uptake behavior. Both the fillers are inserted by physical and chemical gelation methods where most of the chemical gelation, i.e., covalent approaches, results in better physical properties compared to their physical gels. Physical gels occur due to supramolecular assembly, van der Waals interactions, electrostatic interactions, hydrophobic associations, and H-bonding. For chemical gelation, in situ radical triggered gelation mostly occurs.
\end{abstract}

Keywords: nanofillers; hydrogel; mechanical robustness; water uptake; gelation

\section{Introduction}

Hydrogels are three-dimensional networks of hydrophilic polymers showing volume expansion against water molecules. Hydrogels can be prepared either by chemical crosslinking method or physical interactions [1]. When hydrogels are in contact with water molecules, water molecules imbibe the hydrogel matrix, which is called swelling of hydrogel $[2,3]$. Hydrogels are also stimuli-sensitive, and the sensitivity is seen generally in their volume expansion which is also known as actuation behavior of hydrogels [4]. Due to their high water content, hydrogels can be used in biomedical applications, agricultural applications, and absorption-based applications. The mechanical and thermal behaviors of any hydrogels can be tuned by incorporating fillers into the hydrogel matrix. Fillerincorporated hydrogels are called composite hydrogels [5]. When the filler dimension is a nanometer range, then the hydrogel is called a nanocomposite hydrogel. In addition to the mechanical and thermal properties of composite hydrogels, they also show optical, electrical, magnetic, and tribological properties [6].

Filler materials for any hydrogel can be categorized into various types. Fillers are particulate materials/additives introduced into polymer matrices to improve their properties and sometimes to reduce the cost of the end product [7]. The introduction of fillers into hydrogels was initially to bring them out to enhance their mechanical and thermal properties [8,9]. However, recently, lots of works have been performed where composite hydrogels are used for tissue engineering scaffolds [10-14], drug delivery devices [15,16], smart sensors [17-20], separation and purification devices [21-24], and artificial tissues and muscles [25-28]. As hydrogels accommodate water inside their pores, they show muscle mimetic behaviors. In artificial soft robotics and deformation, sensors are also developed by using hydrogel matrices [29]. Fillers of hydrogels can be isotropic or anisotropic in nature [30]. Isotropic fillers are normally spherical in shape, whereas anisotropic fillers possess specific shapes [31]. In most of the cases, anisotropic fillers are desirable fillers for hydrogel matrices to improve their mechanical properties and uniaxial stretching strength. In this review, the aim is to cover the potential and the mostly used fillers for hydrogels and the fabrication approaches of composite hydrogels. 
In addition to this, we also discuss how the filler materials impact the mechanical properties of composite hydrogels. According to the synthesis procedures, composite hydrogels can be prepared either by in situ method or simple blending method. For preparing via in situ approach, surface property and the functional groups of filler materials play significant roles. The most common anisotropic filler is phyllosilicates. Phyllosilicate minerals were used in the early stages of polymer composite fabrication. Later, graphene, nanotubes, MXenes, and quantum dots drew attention for improving physical properties to a large extent. Among these aforementioned fillers, quantum dots are spherical in shape with sub-nanometer diameter. Herein, the hydrogel fabrication methods by using individual fillers are also discussed.

\section{Fabrication of Composite Hydrogels}

Nanocomposite hydrogels are prepared by introducing fillers into the polymer phase. The strategies are categorized into two sections. One is chemical crosslinking approach where the polymer phase is crosslinked by chemical crosslinker, and another one is pure the blending method.

\section{Crosslinking Approach}

Hydrogels are crosslinked network assembly. Composites hydrogels are prepared by incorporation of fillers into a polymer system. The system is either chemically crosslinked or physically. Fillers also take part in the gelation reaction. Generally, the most common approach is using vinylic monomers and dispersed fillers to intermix together followed by gelation. The gelation is performed by several approaches. Free-radical polymerization is the most common way for chemical hydrogel preparation. Depending on the microstructure and morphology, hydrogels are porous in nature. The porosity can be tuned by altering their monomer concentrations and other synthesis parameters. For the free-radical polymerization process, vinylic monomers are taken with association of divinylic crosslinker, leading eventually to a chemically crosslinked insoluble gel mass. When single monomer is used, then the hydrogel is called homopolymer gel, whereas for more than one monomer, the gel is named copolymer gel. Two polymer phases are also used to prepare an interpenetrating polymer network (IPN). IPNs are a special class of gel mass where at least two polymer chains are intertwined among them. If one phase of the IPN is crosslinked, then the system is called semi-IPN. In case of IPNs, both the polymeric networks are crosslinked. Figure 1 shows a typical example of IPN hydrogel which was prepared from gelatin derivative and alginate. In this article, the author used two types of crosslinking; one is chemical and another one is ionic [32]. Both types of hydrogels show high mechanical robustness and thermal stability. The diffusion behavior of the hydrogel is controlled over the internal morphology and porosity. When hydrogels are dipped into water, water molecules are imbibed into the gel matrices followed by volume expansion. Because of their high polarity, the gel system is very prone to water uptake. Poly(N-isopropyl acrylamide) (PNIPAAm) and its copolymers, for example, have received a lot of interest in numerous research on temperature-responsive polymers because of their capacity to reversibly swell in aqueous solutions [33]. Copolymerizing with hydrophobic or hydrophilic comonomers has been used to modulate LCST polymers [34]. Hydrophilic comonomers were added to the formulation to raise the LCST profile, but hydrophobic comonomers had the reverse effect [35]. These experiments validated the promise of polymers based on isopropyl acrylamide, although these systems have drawbacks due to their low biodegradability [36]. Other biodegradable monomers can be used to help overcome these constraints [37]. When combined with a thermosetting hydrogel such as PNIPAAm, the fundamental required monomers are biodegradable and nontoxic products [38]. This system's properties make it an excellent option for an injectable matrix for in vivo applications requiring degradation [39]. The resulting hydrogel may be used for tissue engineering, cell sheet engineering, and drug administration over a long period, while the breakdown mechanism is more predictable [40]. In the wide literature survey, a 
few articles on bone tissue engineering methodologies have focused on PNIPAAm hydrogel scaffolds. Despite progress, creating a hydrogel tissue-engineering scaffold utilizing both hydrophilic and hydrophobic polymers remains a challenge. In this work, we built on our prior research into the design and construction of novel biodegradable scaffolds, as well as the evaluation of their impact on bone tissue engineering. The PNIPAAm solgel transition and the cyclodextrin (CD) and adamantane (Ad) host-guest interactions provide noncovalent crosslinking. Ad can be employed as guest molecules, as $\mathrm{CD}$ has an interior hydrophobic cavity. The host polymer CD-g-PNIPAAm was synthesized to create noncovalent crosslinked gel structures with lively and reversible phase-transition behavior in water [41]. Furthermore, ammonolysis of amantadine hydrochloride with generation 2.5 polyamidoamine dendrimer through its outer ester groups yielded the guest polymer G2.5 PAMAM-Ad. Their self-assembly might happen quickly. To make a DA crosslinked hydrogel, chondroitin sulfate (ChS) is commonly treated with furfurylamine. The PEG-AMI crosslinker was created by combining maleimido (AMI) with polyethylene glycol (PEG). The following chemical entities' noncovalent crosslinking allowed for fast gelation after injectable distribution in vivo, exhibiting the jointly effected noncovalent contacts and chemical crosslinking activities. The water content of the dual crosslinking hydrogel may be measured up to 98 percent, indicating that the hydrogel is permeable and biocompatible, making it more suitable for biomedical applications. Ribeiro et al. published a study in 2017 that recommended employing electrochemical polymerization (ECP) to create a highly porous N-isopropylacrylamide (PNIPAAm) and hydroxyapatite (HAp) scaffold as a precursor for bone tissue regeneration [42]. The polymerization of acrylic monomers has received a lot of attention in the last decade due to the special benefits of the ECP method, such as flexibility in the creation of highly biocompatible electrode coatings used in medical devices.

Injectable, biodegradable, and chemically crosslinkable poly(N-isopropyl acrylamide)based scaffolds for bone tissue engineering applications were prepared and characterized [43]. This review focuses on $\mathrm{pH}$ - and temperature-responsive injectable hydrogels, as well as their utility in the administration of long-acting medicines [44]. Different synthetic and natural parts have been presented as the basis for new goods [45]. The majority of researchers have focused on creating innovative polymerization processes that can create polymers with a variety of architectures while avoiding the use of large volumes of hazardous solvents. Main elements, such as hydrophilic/hydrophobic equilibrium in molecular structure, have been altered in order to build hydrogels with desired qualities [46]. With the continued efforts of researchers throughout the world, we believe that patients will benefit from $\mathrm{pH}$ - and temperature-responsive hydrogels in the near future.

For preparing composite hydrogels, filler materials are initially dispersed to disaggregate the filler lumps. Hydrophilic fillers are highly aggregated because of their surface energy. The dispersed fillers are taken in monomer solution followed by gelation. This approach is called in situ gelation technique. Figure 2 shows the in situ gelation technique, where natural clay is used as the filler material. 


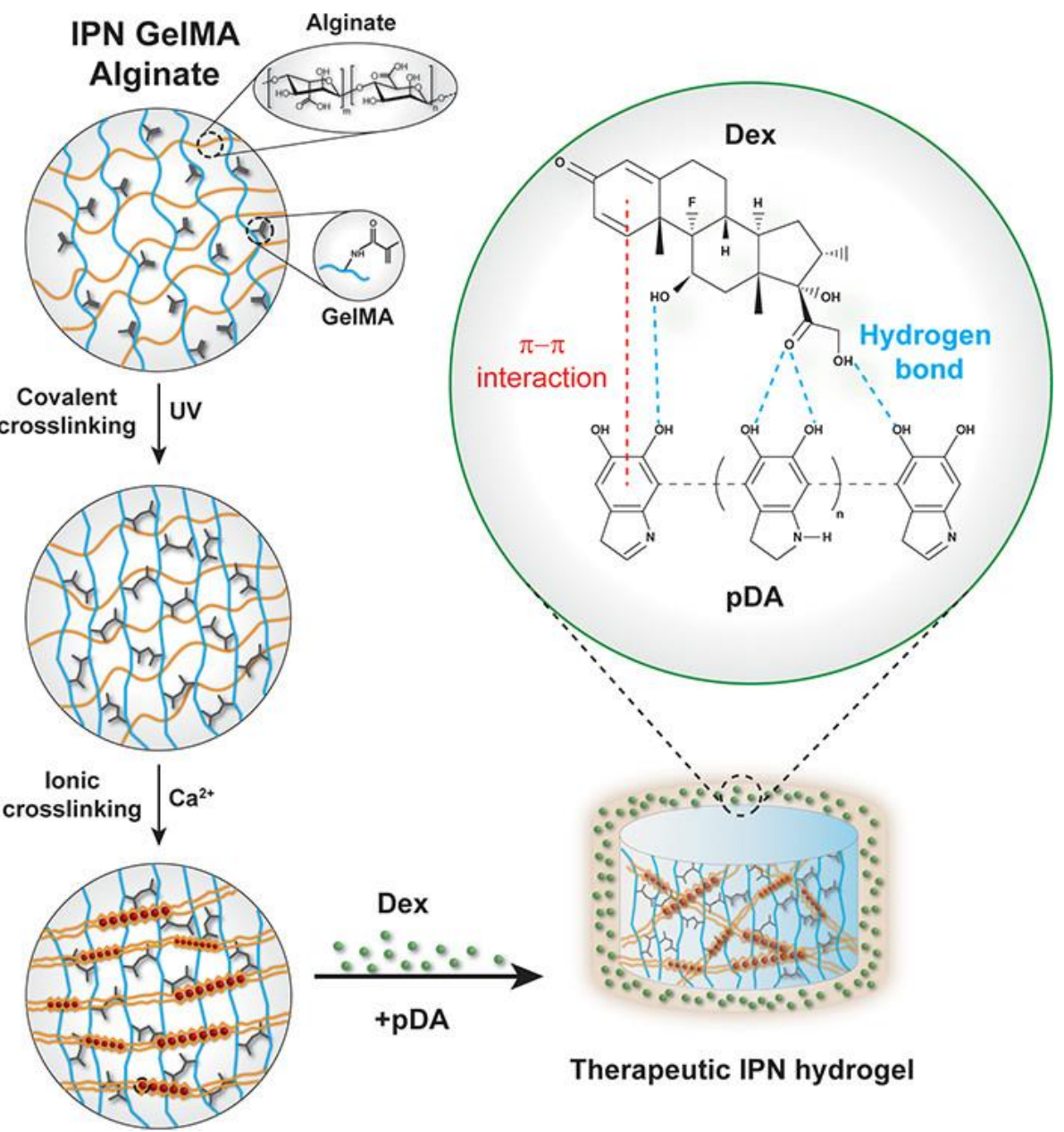

Figure 1. Schematic representation of synthesis of IPN-type hydrogel. Reproduced with the permission of [32], Copyright 2018 American Chemical Society.

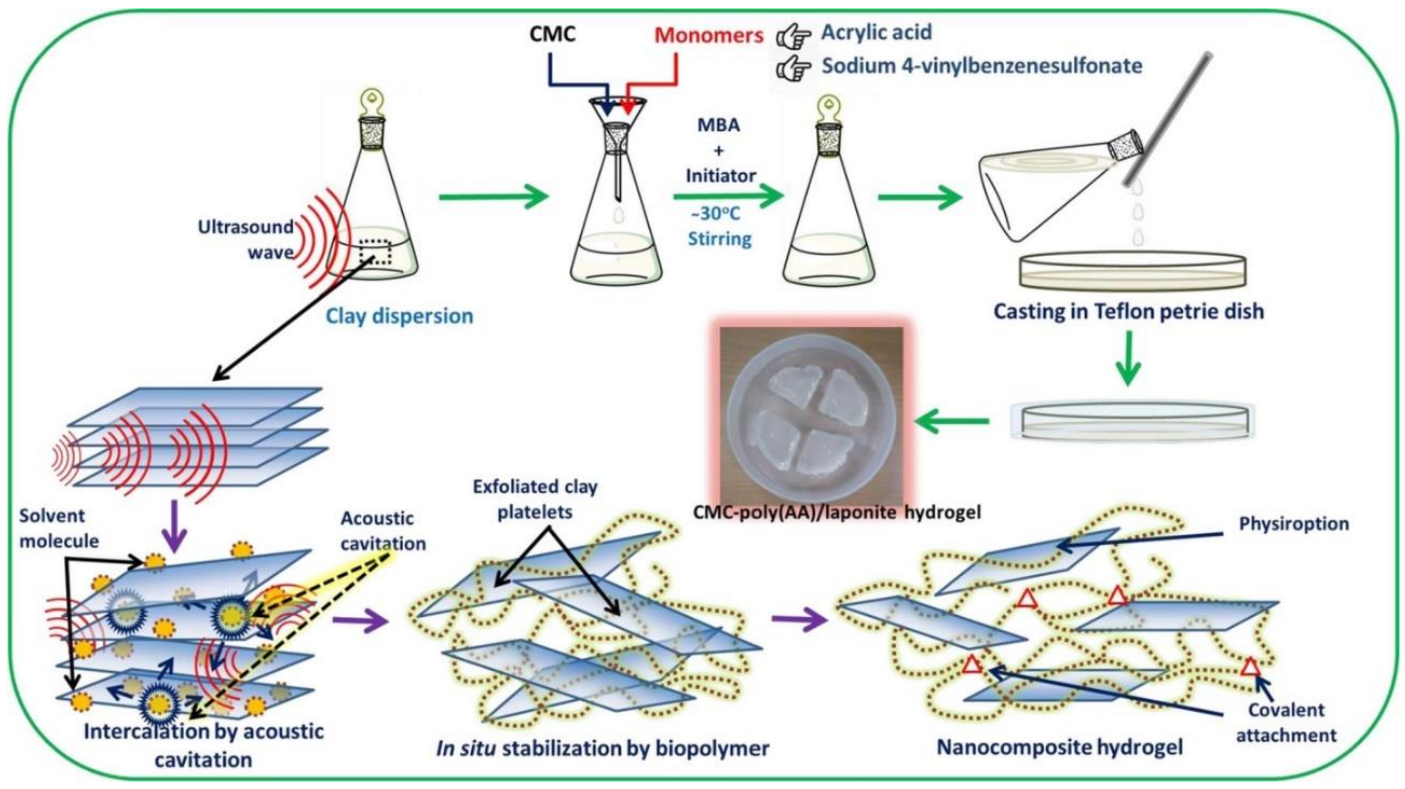

Figure 2. Synthesis of in situ laponite based semi-IPN composite hydrogel. Reproduced with the permission of [47], Copyright 2020 Elsevier. 


\section{Blending Approach}

In comparison to crosslinked hydrogel synthesis, the blending approach is a less costly and energy-intensive procedure. Fillers are not frequently functionalized in this manner. The fillers are simply combined with the polymer system and crosslinked in this scenario. Filler particles are evenly disseminated into a polymer solution in this process, and the entire solution is then crosslinked. To make composite hydrogel, a significant number of filler materials may be accommodated inside hydrogel matrices using this method. Poly(vinyl alcohol) (PVA) was gelled by borax to make a clay-based composite hydrogel, as previously reported [48]. Clay-based blend hydrogel with high adsorption capability was developed by a group of researchers, as depicted in Figure 3 [49]. In this hydrogel manufacturing, polymers that are crosslinked by tiny molecules are preferred [50]. PVA was also crosslinked with glutaraldehyde in another study to create natural fiber-based composite hydrogels [51]. Starch, alginate, carrageenan, albumin, and chitosan are some of the biopolymers employed in this method, and they are all easily crosslinked [52,53].

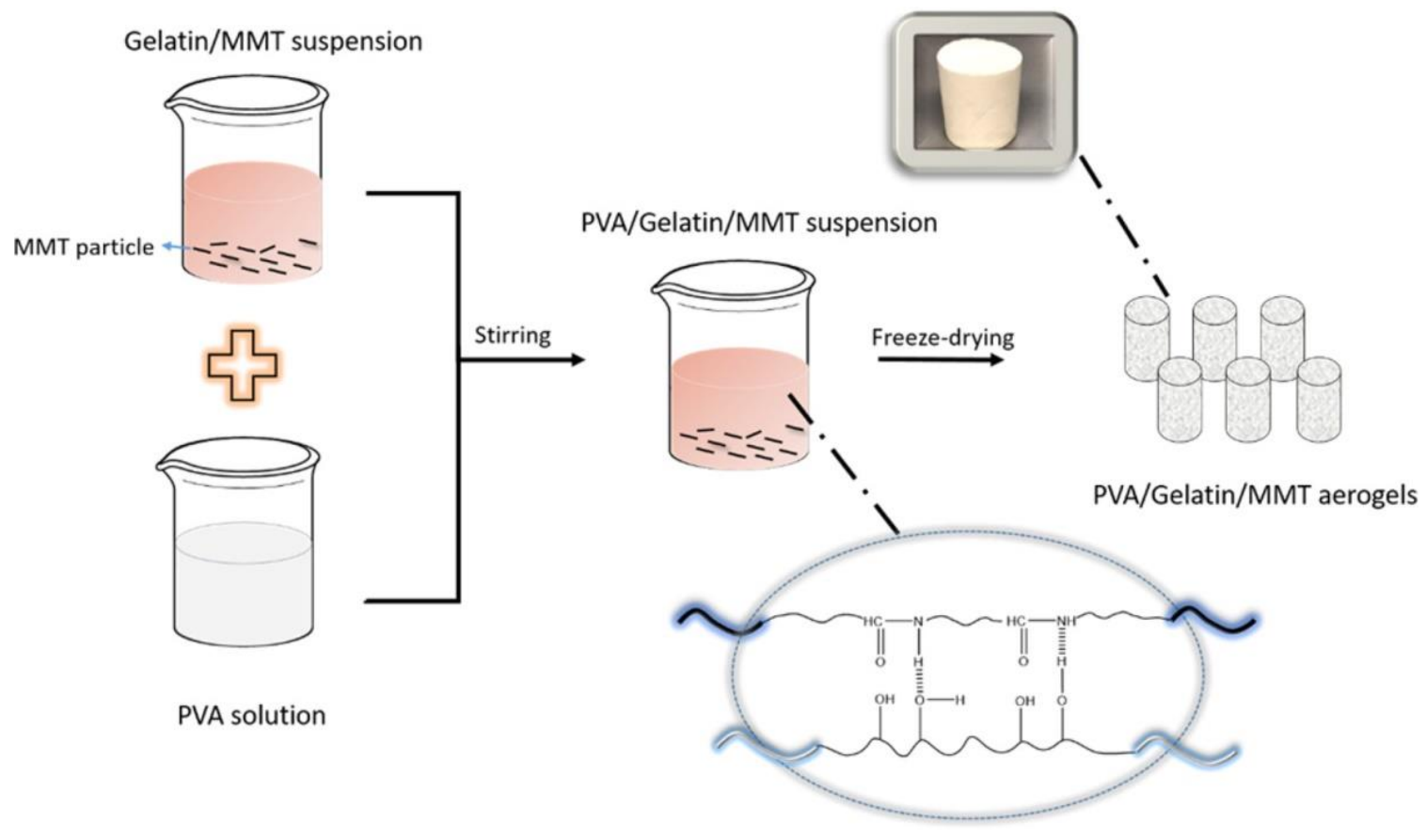

Figure 3. Blending approach to synthesize composite hydrogel. Reproduced with the permission of [49], Copyright 2017 American Chemical Society.

\section{Clay-Based Hydrogels}

Clays are the naturally occurring minerals containing aluminosilicates. In most of the cases, they are phyllosilicates having variable quantities of alkali metal cations. Naturally occurring clays consist of alternative silicate and aluminate layers in their crystal structures. Depending on their arrangement, they can be categorized into 1:1, 2:1, and 2:2 aluminosilicates [54]. Due to their abundance in nature, very low toxicity, and copiousness, they are an economically feasible and environmentally accepted material for several composite preparations [55]. Clay minerals are used as reinforcement for polymer matrices, with an important role played in enhancement of mechanical robustness and water uptake behavior in preparing composite hydrogels. Moreover, clay minerals are also very significant for adsorption capabilities. Very small amounts of clay minerals in hydrogel matrices do not interfere with their refractive indices drastically. Commonly, clay minerals are incorporated into hydrogels by using in situ polymerization techniques in solution phase. For fabrication of clay-based hydrogels, the process takes place in a single step. Initially, clay particles are dispersed into water followed by an addition of monomer, crosslinker, and initiator. After completion of the gelation reaction, the system turns into a gelled mass which is insoluble 
in water. The hydrophilic polymeric chains are susceptible to adhere to the clay surfaces because of their comparable surface energies. Phyllosilicates contain clay tactoids which have several hydrophilic functional groups. In general, hydrophilic polymer chains are physically adsorbed onto those clay tactoid surfaces. Several metal ions which are kept in the gallery gaps of phyllosilicate sheets can be removed by some organic treatment. These types of clays are called organically modified clays. Organically modified clays are easy to disperse in polymer matrices to add physical and mechanical characteristics to the final systems. Haraguchi et al. developed poly(N,N-dimethylacrylamide) and clay-modified composite hydrogel (Figure 4) and showed a reinforcement effect induced by the presence of filler particles [56]. The hydrogel showed $\sim 1500 \%$ elongation at break in ambient conditions. Table 1 shows the different composite systems with the corresponding monomers, crosslinkers, and fillers used for fabrications. In another work, synthetic laponite clay was used as reinforcement for polyacrylamide (PAAm)-based composite hydrogel with high shear modulus [57]. Hydroxyethyl starch and 2-hydroxyethyl methacrylate (HEMA) were used as gel matrix where organically modified montmorillonite (MMT) showed excellent water uptake behavior in room temperature [58].

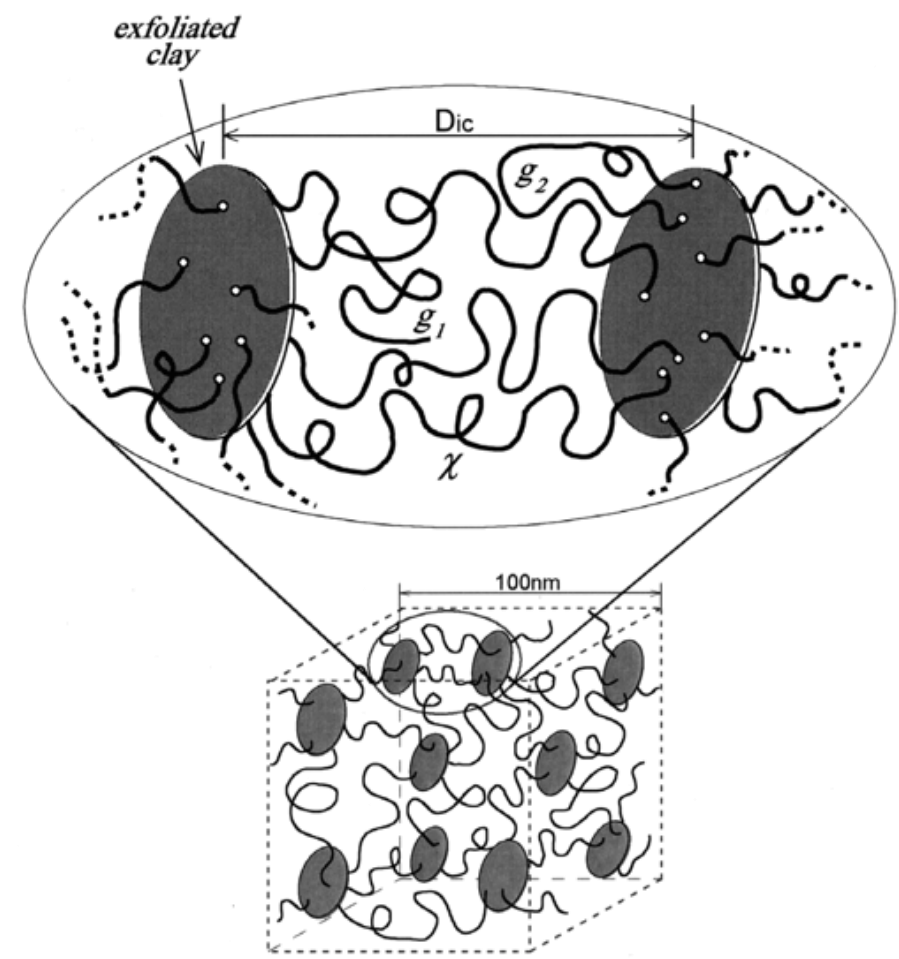

Figure 4. Microstructure of clay-polymer hydrogel. Reproduced with the permission of [56], (C) 2003 American Chemical Society.

Table 1. Clay-reinforced composite hydrogels and their fabrication parameters.

\begin{tabular}{ccccc}
\hline Monomer & $\begin{array}{c}\text { Polymerization } \\
\text { Method }\end{array}$ & Clay Filler & Crosslinker & Ref. \\
\hline AAm/AMPS & Solution & MMT & MBA & {$[59]$} \\
AA & Solution & Bentonite & Sugar & {$[60]$} \\
Chitosan-g-AA & Solution & MMT & MBA & {$[61]$} \\
AAm-AMPS & Solution & MMT & MBA & {$[62]$} \\
PS-g-AA & Solution & MMT & MBA & {$[63]$} \\
AA & Solution & MMT & MBA & {$[64]$} \\
AA-NVP & Solution & MMT & MBA & {$[65]$} \\
\hline
\end{tabular}


Table 1. Cont.

\begin{tabular}{|c|c|c|c|c|}
\hline Monomer & $\begin{array}{c}\text { Polymerization } \\
\text { Method }\end{array}$ & Clay Filler & Crosslinker & Ref. \\
\hline AA-AAm & Solution & Sepiolite & MBA & [66] \\
\hline Starch-g-AA & Solution & MMT & MBA & [67] \\
\hline AA-DAC & Solution & MMT & MBA & [68] \\
\hline CMC-g-AA & Solution & MMT & MBA & [69] \\
\hline Chitosan-g-AA & Solution & MMT & MBA & [70] \\
\hline $\mathrm{AA}^{\circ}$ & Solution & Sepiolite & MBA & [71] \\
\hline AA & $\begin{array}{l}\text { Inverse } \\
\text { suspension }\end{array}$ & MMT & MBA & [72] \\
\hline $\mathrm{AA}$ & Solution & MMT & MBA & [73] \\
\hline $\mathrm{AA}$ & Solution & OMMT & MBA & [74] \\
\hline MAPDMSP & Solution & OMMT & PEGDMA & [75] \\
\hline $\mathrm{AA}$ & Solution & O-ATA & MBA & [76] \\
\hline HES-HEMA & Solution & OMMT & Clay & [58] \\
\hline AAm & Solution & ATA & MBA & [77] \\
\hline AA-AAm & Solution & SH-OMMT & MBA & [78] \\
\hline AA & $\begin{array}{l}\text { Inverse } \\
\text { suspension }\end{array}$ & OMMT & MBA & [79] \\
\hline $\mathrm{AA}$ & Solution & Hydrotalcite & MBA & [80] \\
\hline SA & Solution & AR-O-R & MBA & [81] \\
\hline SA & Solution & O-vermiculite & MBA & [82] \\
\hline SA & solution & Rectorite & MBA & [83] \\
\hline AA-AAm & $\begin{array}{l}\text { Inverse } \\
\text { suspension }\end{array}$ & Hydrotalcite & MBA & [77] \\
\hline Starch-g-AA & Solution & Bentonite & MBA & [84] \\
\hline AAm-AMPS & Solution & MMT & $\begin{array}{l}\text { Chromium } \\
\text { triacetate }\end{array}$ & [77] \\
\hline AAm & Solution & Laponite & Clay & [85] \\
\hline $\mathrm{AA}$ & Solution & Diatomite & MBA & [86] \\
\hline $\begin{array}{l}\text { Starch-g-AA- } \\
\text { AAm }\end{array}$ & Solation & MMT & MBA & [87] \\
\hline $\mathrm{AA}$ & Solution & Smectite & MBA & [88] \\
\hline NSC-g-AA & $\begin{array}{l}\text { Inverse } \\
\text { suspension }\end{array}$ & ATA & MBA & [89] \\
\hline AA-AAm & Solution & Kaolinite & MBA & [90] \\
\hline Collagen-g-AA & Solution & Kaolin & MBA & [91] \\
\hline $\begin{array}{c}\text { Sodium } \\
\text { alginate-g-AA }\end{array}$ & Solution & $\mathrm{SH}$ & MBA & [92] \\
\hline
\end{tabular}

\section{Graphene Oxide- and Graphene-Based Hydrogels}

Graphene oxide (GO) sheets are single-layered graphene sheets having oxygenated polar groups such as hydroxyl, carboxyl, and epoxides. Due to their high surface energy and abundant functionalities, they are easily compatible with the hydrophilic polymers $[93,94]$. Hydrogels consist of hydrophilic polymer chains where GO nanosheets are incorporated by various approaches. The most common method to prepare GO- or graphene-based hydrogels is the in situ gelation technique [95]. In this technique, GO-derived fillers are dispersed into a monomer solution followed by the addition of hydrogelator and initiator. The whole dispersion normally turns to gel within a finite time. In this process, GO sheets are anchored to the hydrophilic polymer chains, enhancing mechanical properties of the composite hydrogel. 


\section{Radical Polymerization Method}

Due to this favorable interaction with hydrophilic polymers, there are cases where GO platelets act as physical crosslinker inducing hydrogel formation. Recently, Adhikari et al. reported GO-based hybrid hydrogel via physical assembly approach [96]. In this study, they took polyamines with spermine and GO which became gel at room temperature. Polyamine physically adsorbed on the GO surface, and physical crosslinking was achieved. Self-assembly is a widely adopted strategy to prepare hybrids at macroscopic scale. The outcomes provide novel properties and physiological acceptance to be used as biomaterials. The formation mechanism follows the noncovalent pathways such as aromatic stacking, electrostatic attractions, hydrogen bonding, and van der Waals interactions. These in situ self-assembled gels are also called supramolecular gels, where the gelators are normally present as small molecular precursors. When GO is introduced, it forms $\pi-\pi$ interactions between GO nanosheets that promote instant gelation. Shi et al. reported GO-based hydrogel by this method also by using GO and DNA [97]. Similarly, Zhang et al. developed self-assembled GO loaded hydrogel in presence of glucono- $\delta$-lactone [98]. In another work, cyclodextrine was used in association with GO to prepare GO-based hydrogel [99]. Block copolymer was used with $\mathrm{GO}$ dispersion to prepare temperature responsive hydrogel via sol-gel reversion technique [100].

The covalent crosslinking method to prepare GO-based hydrogel is performed via the radical initiation method. In this method, GO dispersion is taken in monomer solution followed by the addition of free radical initiators, and the gel forms. Bardajee and Hooshyar developed thermoresponsive nanogels by using N-isopropylacrylamide (NIPAM) monomer and GO. In this work, they used divynilic crosslinker and thermal initiator for preparing hydrogels [101]. These hydrogels are desirable for holding small molecules, such as drugs, and they showed sustained release behavior. Similarly, GO was introduced as a building block for reinforcement action in hydrogel in the presence of acrylamide monomer solution [102]. These hydrogels are tough and are used as actuator-based applications. In a new material based on a mixture of GO and bacterial cellulose intended for tissue engineering, GO was excellently dispersed and attached onto polysaccharide component showing a substantial improvement of the scaffold: a tiny amount of GO of $0.48 \mathrm{wt} \%$ led to an increase in the Young's modulus by $120 \%$ when compared to the material consisting of bacterial cellulose alone [103]. In another example of GO-PVA-based hydrogel, GO component was functionalized by using glutamic acid in order to improve gel biocompatibility [104]. Moreover, due to their carboxylic groups, the glutamic acid residues anchored onto GO sheets made crosslinking more effective in the system and enhanced dispersibility of GO into the gel matrix. Chen et al. reported a double-network hydrogel where GO was used to prepare a first variant form of hydrogel [105]. The final version of hydrogel was described as being useful as an anticancer drug delivery system. $\mathrm{GO}$ was functionalized with cyclodextrin by hydrothermal reaction followed by free-radical polymerization. Zhang et al. developed GO/polyacrylamide-based compressible hydrogel by free-radical initiation method [106]. Here, they used two polymers mingled together to form a GO-reinforced semi-interpenetrating network hydrogel. Polyacrylamides are prone to physically attach with GO basal groups, forming $\mathrm{H}$-binding. These materials are tough and compressible because of their dual crosslinking inside a gel matrix. H-bonding between GO and polymer polar functionalities act as surplus crosslinking, which affects their delayed rupturing behavior.

Reduction of GO, i.e., reduced graphene oxide (RGO), is a potential verity among the 2D materials because of their high electrical conductivity, thermal conductivity, high strength to weight ratio, and fast stress-dissipation behaviors [107]. RGO-based hydrogels are already developed by several groups to promote high-strength electrically conductive scaffold-type material. RGO-based hydrogels are also prepared the similar processes to those adopted for GO-based hydrogels. The most common method is in situ free-radical gelation. Graphene sheets are difficult to disperse in aqueous medium compared to GO because of their low polarity. RGO-reinforced stretchable semi-IPN hydrogel was reported 
by using $\mathrm{k}$-carrageenan as biopolymer component (Figure 5) [108]. These hydrogels are tough and stretchable and showed biodegradability. Moreover, RGO content also affects their porosity, as determined by microcomputed tomography ( $\mu-\mathrm{CT})$ technique, as shown in Figure 6. The porosity was assessed in various directions as layouts are seen in the respective image which corroborates uniformity of porosity throughout the whole composite hydrogel. Photopolymerization is also another way to prepare polymer composites [109]. Tang et al. reported photopolymerized bovine serum albumin crosslinked hydrogel which was used to adsorb GO followed by in situ reduction to transform into RGO [110]. These hydrogels are flexible in nature and showed compressive strength of $\sim 160 \mathrm{kPa}$ in wet condition. Jiao et al. reported noble metal-deposited RGO nanoparticles and prepared composite hydrogels with it [111]. These hydrogels showed potential catalysis behavior against organic pollutants in aqueous environments. Table 2 shows detailed information of various graphene-based composite hydrogels and their preparation approaches.

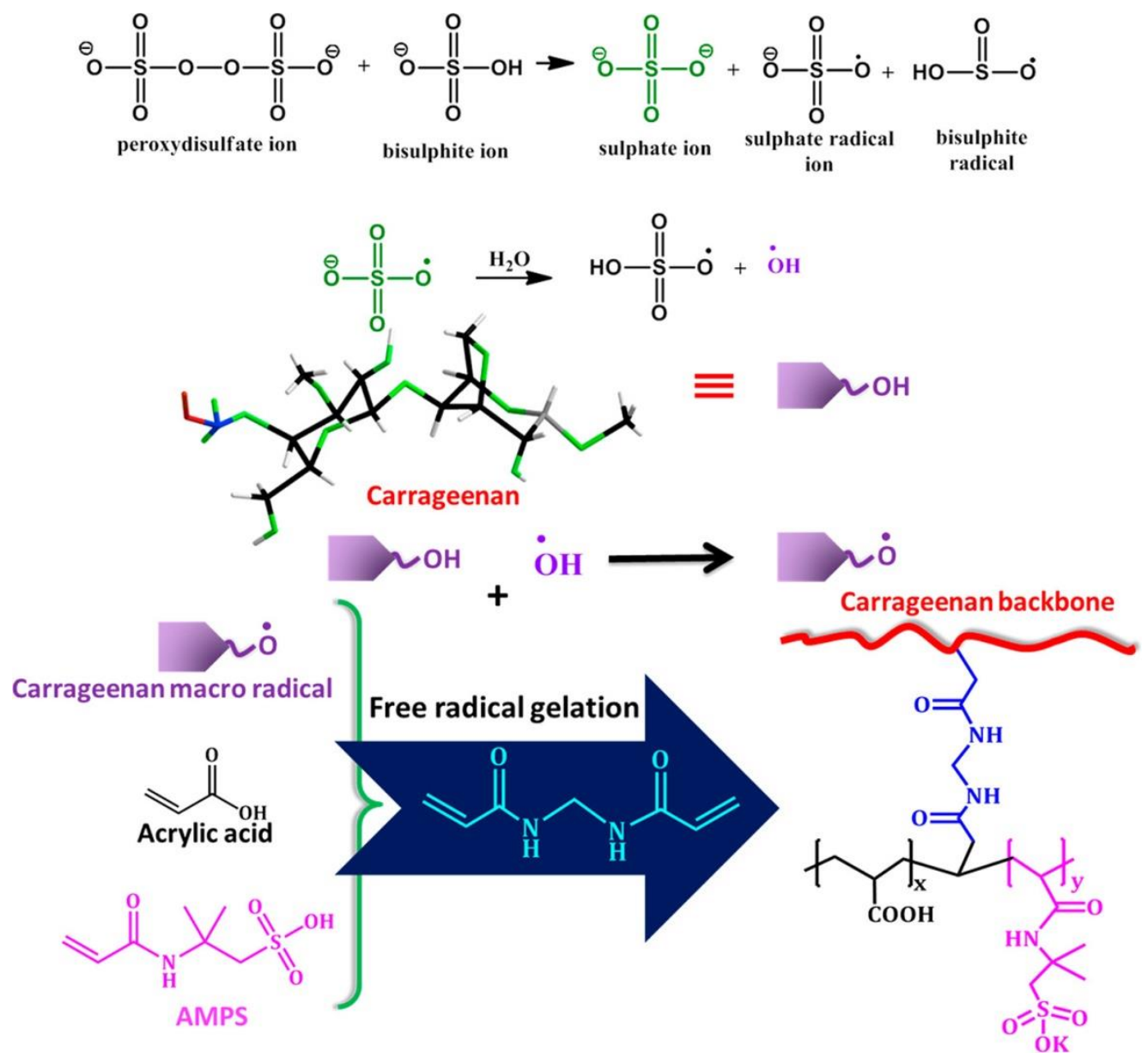

Figure 5. Schematic illustration of redox imitator assisted gelation. Reproduced with the permission of [108], Copyright 2018 American Chemical Society. 


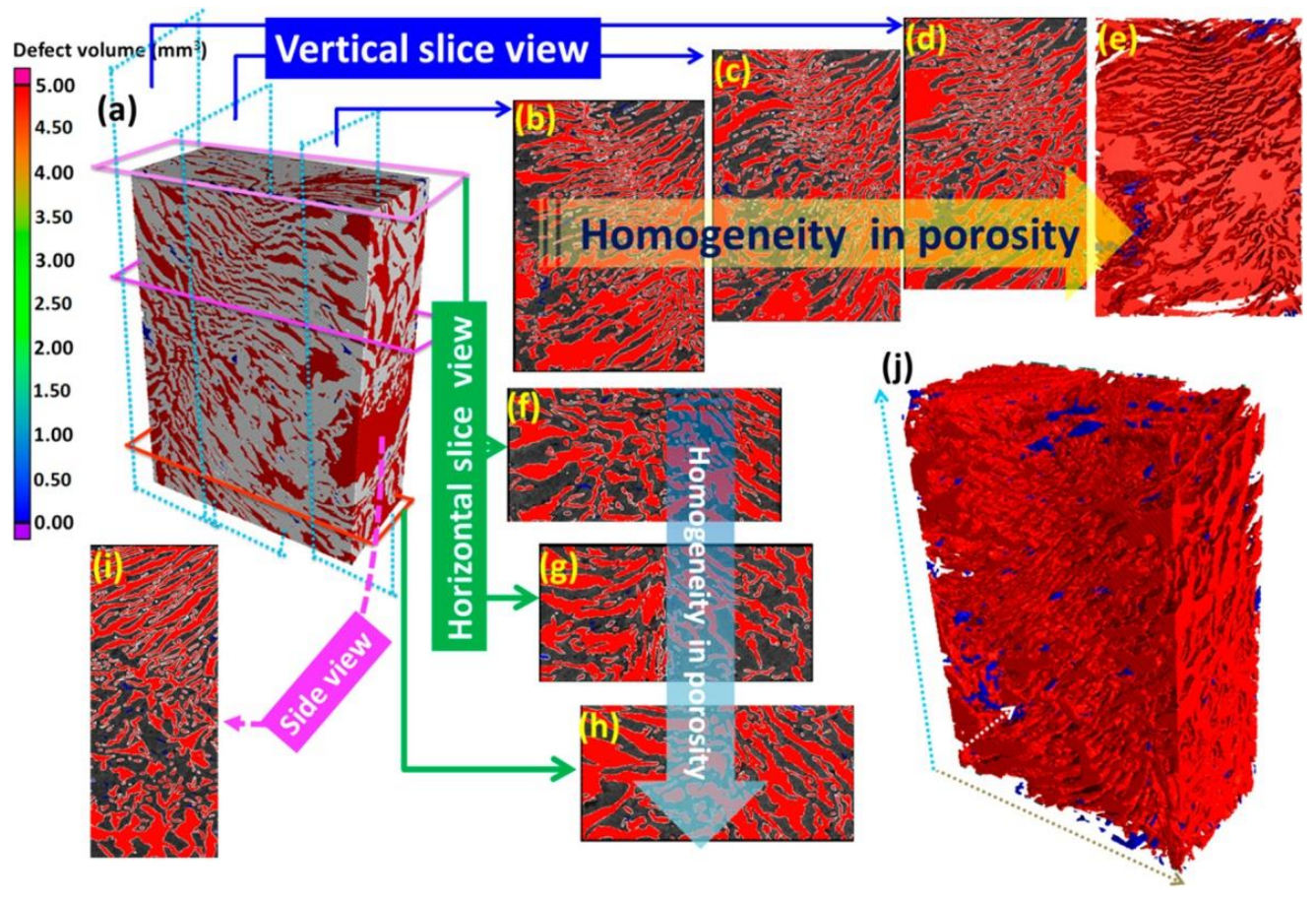

Figure 6. (a) 3D view of RGO-hydrogel monolith obtained by $\mu-C T$. (b-e) Vertical slice view after reduction by software. (f-h) Horizontal slice view. (i) Side view. (j) 3D porous structure with connected (red portions) and nonconnected (blue domains) pores. Reproduced with the permission of [108], Copyright 2018 American Chemical Society.

\section{Synthesis Method by High-Energy Irradiations}

GO, sodium acrylate (SA), and acrylic acid (AAc) were copolymerized and crosslinked using gamma irradiation to create a $\mathrm{pH}$-responsive hydrogel [112]. Cefadroxil was employed as a model medication, and SA is a natural polymer. The synthesis of GO/(AAc-coSA) hydrogels began with the manufacture of GO using a modified Hummers' technique, followed by the mixing of AAc and SA in the GO solution, and finally the irradiation of 60Co gamma rays $(20 \mathrm{kGy}, 10.28 \mathrm{kGy} / \mathrm{h}$ ) for $117 \mathrm{~min}$. The manufacturing of $\mathrm{GO}$ in a GO/(AAc-Co-SA) hydrogel matrix was studied, and swelling tests revealed that the presence of GO in the hydrogel increased and controlled swelling at various $\mathrm{pH}$ buffer solutions ( $\mathrm{pH} 1$ and 7). The GO/(AAc-co-SA) might be employed for the drug delivery system, according to the results of a profile analysis of drug release.

\section{Enzyme-Driven Synthesis Method}

Using $\beta$-glycerophosphate (GP) enzyme as a crosslinker and Tris(2,2bipyridyl)dichlororuthenium(II) as an anticancer agent, researchers created a unique low-temperature hydrogel of CS/GO [113]. The scaffold was made by combining GO, CS, and GP in various ratios, with the addition of acetic acid to improve CS solubility. GP has been found to have a unique feature in that it keeps the CS solution in a liquid form at physiological $\mathrm{pH}$, but when heated to physiological temperature, it tends to gel. Studies on gelation duration and temperature revealed that increasing GP concentration decreased gelation temperature. Furthermore, increasing the $\mathrm{GO}$ concentration decreased the gelation temperature to $33^{\circ} \mathrm{C}$ and the gelation period to $9 \mathrm{~min}$. When compared to the control experiment CS hydrogels, the drug release profile of the scaffold demonstrated that it enhanced drug delivery. In another work, it was described that an injectable hydrogel was made by in situ enzymatic crosslinking of 4-arm polypropylene oxide (PPO)-polyethylene oxide (PEO)-tyramine (Tet-TA) with varying amounts of GO oxidation [114]. The increase in oxidation level and surface area of GO was observed using X-ray photoelectron spectroscopy (XPS) and FTIR characterizations. Tet-TA increased the dispersibility of the hydrogel, whereas GO improved its mechanical properties. 
This hybrid scaffold was shown to be biocompatible and nontoxic, implying that it might be employed as an injectable hydrogel for medication delivery and tissue engineering.

\section{Functional Group-Induced Gelation}

Composite GO hydrogel using carboxymethyl chitosan (CMCS), hyaluronic acid (HA), and fluorescein isothiocyanate to exhibit chemically crosslinked GO hydrogel via interaction with functional groups (FI) was reported [115]. This hydrogel was made in two steps: first, GO was modified with CMCS via an amide linkage between the $-\mathrm{NH} 2$ group of CMCS and the - $\mathrm{COOH}$ group of GO; then, the amino group in GO-CMCS was conjugated with carboxylic groups of HA and FI to produce the final scaffold (GO-CMCSFI-HA). FTIR and transmission electron microscopy (TEM) were used to validate the hydrogel scaffold. DOX was employed as a model drug, with a drug-loading capacity of $95 \%$. A study of drug release profiles revealed that the best drug release occurred at pH 5.8, not pH 7.4. The hydrogel cytotoxicity on HeLa cells was found to be nontoxic, indicating that this scaffold might be used as a nanocarrier for targeted anticancer drug delivery. Paclitaxel (PTX) anticancer medication delivery was described using GO-PEG nanocomposites [116]. This nanocomposite was made via an amide linkage technique with six armed PEG and then functionalized with amine groups in an aqueous solution at ambient temperature. GO-PEG particle sizes varied from 50 to $200 \mathrm{~nm}$, according to AFM analysis. The biocompatibility and nontoxicity of GO-PEG in A549 and MCF-7 cell lines were demonstrated in a bioassay. The drug-loading capacity was $11.2 \mathrm{wt}$. percent after PTX was conjugated with GO-PEG through hydrophobic contacts and stacking. Biological testing on A549 and MCF-7 cells demonstrated that GOPEG/PTX nanocomposites are more cytotoxic than PTX alone, with better penetrability. Furthermore, the cytotoxicity of GO-PEG/PTX nanocomposites employing FI was validated by inverted fluorescein microscopy. Wu et al. used a click chemical procedure to create a covalently bound heparin-GO (Hep-GO) nanocarrier [117]. The azide group and propargylamine were used to functionalize GO and heparin polysaccharide, respectively. Model medications DOX and granulocyte colony-stimulating factor (G-CSF) were chosen. G-CSF was given either after the CT treatment to restore white blood cells or before the CT treatment to increase the generation of stem cells in the bone marrow. UV-Vis spectroscopy was used to investigate Hep-GO colloidal stability in aqueous solution. Hep-GO/DOX/G-CSF demonstrated great thermal stability in an in vitro study, and the drug was delivered over a lengthy period of time with low drug cytotoxicity. Overall, the findings suggest that Hep-GO might be used as a nanocarrier scaffold for many anticancer medicines.

Table 2. Graphene-based hydrogels, their preparation methods, and reinforcement loading concentrations.

\begin{tabular}{ccccc}
\hline Hydrogel Matrix & Fillers & Loading (wt\%) & $\begin{array}{c}\text { Mechanical } \\
\text { Strength }\end{array}$ & Ref. \\
\hline PAM & GO & 0.03 & $65.5 \mathrm{kPa}$ & {$[118]$} \\
PAA & GO & 0.5 & $777.3 \mathrm{kPa}$ & {$[119]$} \\
poly(AMPS-co-AM) & RGO & 1.0 & $\sim 98 \mathrm{kPa}$ & {$[120]$} \\
PAA & Graphene & 3.0 & $19.09 \mathrm{MPa}$ & {$[121]$} \\
PAM & Graphene & 3.0 & $1.31 \mathrm{MPa}$ & {$[122]$} \\
PAA & Graphene & 0.5 & $0.006 \mathrm{MPa}$ & {$[123]$} \\
PAA & GO & 0.073 & $25 \mathrm{kPa}$ & {$[124]$} \\
PAA-g-amylose & GO & 3.0 & $42.47 \mathrm{MPa}$ & {$[125]$} \\
PAA & Graphene & 2.0 & $411.9 \mathrm{kPa}$ & {$[126]$} \\
PAM/Fe $\mathrm{O}_{4}$ & RGO & 0.15 & $0.945 \mathrm{MPa}$ & {$[127]$} \\
PVA/PEG & GO & 1.5 & $4.2 \mathrm{MPa}$ & {$[128]$} \\
poly(AA-co- & RGO & 2.5 & $488.5 \mathrm{kPa}$ & {$[108]$} \\
AMPS)/carrageenan & GO & 0.3 & $0.25 \mathrm{MPa}$ & {$[129]$} \\
PAA/gelatin & GO & 0.1 & $4 \mathrm{MPa}$ & {$[130]$} \\
PAA & & &
\end{tabular}




\section{Characterization Techniques}

Soft materials are gaining popularity as a "transformable" useful class of materials due to their modest mobility and flexibility, which allows them to easily alter their bulk shape and qualities depending on the circumstances [131]. Gels are soft agglomerates with mechanical qualities that range from soft and weak to firm and robust [132]. In the steady state, gels are characterized as significantly dilute crosslinked systems with no flow [133]. Physical (physical gels) or chemical (chemical gels) linkages, as well as crystallites or other junctions that remain intact inside the stretching fluid, can all contribute to the internal network structure [134]. Most gels combine solvent molecules into a 3D entangled network of dimensionally regulated fibrils and tape-like ordered aggregates made up of gelators; thus far, the majority of functional gels have been synthesized and their physical characteristics examined using polymergelators [135]. Low-molecular-weight gelators (LMWGs) can self-assemble into nano- or microscale network structures, such as fibers, ribbons, sheets, and spheres, in an appropriate solvent, resulting in the formation of 3D networks [136-145], which are interconnected by multiple noncovalent interactions, such as hydrogen bonding, metal coordination, van der Waals interactions, $\pi-\pi$ stacking interactions, and solvophobic forces (hydrophobic forces for hydrophobic interactions) [146-149].

\section{Nuclear Magnetic Resonance (NMR) Spectroscopy}

The capacity of nuclear magnetic resonance (NMR) spectroscopy to explore the surroundings of an individual atomic nucleus and report on the structures and dynamics of the generated networks makes it ideal for studying supramolecular gels [150]. NMR spectra can reveal structural features of components, aggregates formed as a result of interactions, and areas involved in interactions, all of which are important for the dynamic network's stability [151]. The comparatively lengthy relaxation durations of the detected nuclei, on the other hand, make NMR a useful tool for characterization of supramolecular gels [152]. This is akin to having a long memory, as it allows nuclei to absorb knowledge from many locations visited via chemical interactions or molecular movements [153]. As a result, NMR is a useful tool for researching supramolecular gels at the molecular level and for obtaining a dynamic image of supramolecular gels $[154,155]$. In order to discover the structure and relationships of a substance's molecules, ${ }^{1} \mathrm{H}$ NMR probes hydrogen nuclei inside its molecules. Changes in chemical shift can be seen, as well as the creation of supramolecular gels fueled by noncovalent interactions. On the basis of benzo-21-crown-7 produced by orthogonal self-assembly, Huang and coworkers have established a multiresponsive, shape-persistent, and elastic supramolecular polymer network gel [156]. Temperature has an effect on the gel. Heating and chilling can be used to create a reversible gel-sol transition. To offer strong evidence for this gel-sol transition, temperature-dependent ${ }^{1} \mathrm{H}$ NMR spectra were carried out. At a low temperature, the ${ }^{1} \mathrm{H}$ NMR signals for the gelator nearly vanished, indicating substantial intermolecular aggregation. With increasing temperature, the gel eventually transformed into a sol, revealing the original well-dispersed signals.

\section{Diffusion Ordered NMR Spectroscopy (DOSY)}

The use of diffusion ordered NMR spectroscopy (DOSY) to study self-assembly processes from building blocks to the creation of functional nanomaterials is becoming increasingly relevant. DOSY demonstrates its advantage in the characterization of objects of intermediate dimensions ranging from a few ngstroms to several hundred nanometers. DOSY may be used to calculate the translational self-diffusion coefficient $\left(D_{t}\right)$, which is difficult to calculate using other methods as it does not need the separation of species mixtures $[157,158]$. In the absence of any chemical potential gradient, this accounts for the net consequence of thermal motion generated by random-walk processes experienced by particles or molecules in solution [159]. The Stokes-Einstein equation, as well as the thermodynamic parameters (equilibrium constant and $\Delta \mathrm{G}^{0}$ of the aggregative process) of the self-assembly processes, may be used to obtain precise hydrodynamic dimensions (shape and size) of the aggregates based on the $D_{t}$ values [160]. 


\section{Water Uptake}

Changes in the type and concentration of crosslinker, monomer, initiator, and reaction temperature can all affect the swelling capacity of a superabsorbent polymer [161]. The swelling/crosslinker concentration power-law behavior shows that the concentration of the crosslinker has the most dramatic influence among them [162]. In contrast to normal hydrogels, where the usage of a crosslinker is essential, a few studies on hydrogel nanocomposites revealed the opposite [163]. The clay (laponite) worked as a multifunctional crosslinker when it was evenly scattered [164]. The laponite was stated to have a functionality of 50 in Oppermann's work, which was thought to bring large-scale structure [165]. Both chemical crosslinker and clay have been employed in most other experiments [166-169]. While chemically crosslinked hydrogels are brittle when wet, crosslinker-free systems have better bending and flexural capabilities. In general, when the clay concentration of a crosslinker-free hydrogel nanocomposite increases, its swelling capacity decreases [163]. The monomer concentration can also influence the clay content-swelling relationship. Although most superabsorbent composites are made with a low monomer concentration, a larger monomer concentration can result in a higher swelling capacity when the clay loading is significant [170,171]. A crosslinker-free polymerization of AA and AAm using sodium silicate was described, in which the $\mathrm{Si}-\mathrm{O}-\mathrm{C}$ bond is generated due to the reaction of carboxyl groups with silanol groups ( $\mathrm{Si}-\mathrm{OH})$ [172]. The rate of swelling is affected by a number of factors, including particle size, porosity, drying technique, and the structure of the polymer network [161].

\section{Small-Angle X-ray Scattering (SAXS)}

Wilhelm Conrad Rontgen was the first to discover the X-ray, which earned him the Nobel Prize in Physics. SAXS on amorphous materials, which were fundamentally colloidal systems, was first described by P. Krishnamurti in 1920. Following this, there was very little investigation into SAXS. The distinct intensity measurement between background $\mathrm{X}$-ray and scattered beams is the major challenge in detecting X-ray scattering following bombardment with materials. Several designs have been developed since then to enhance the collimation technology. The beam size and slit/pinhole adjustment affect collimation. Collimators come in a variety of shapes and sizes. The pinhole (slit) collimation method, the Kratky collimation system, and the BonseHart channel-cut collimation system is the most common (for very small angles). The photon count in synchrotron X-ray is extremely high, resulting in a high-intensity 1D plot. Furthermore, SAXS has become a practical technique for structure and morphology assessments of a given system in the presence of other interacting materials due to the tunability of X-ray wavelength throughout a drift near to the $\mathrm{K}$ or L edge of a component. Nondestructive X-ray scattering methods can provide details on the crystal structure, chemical composition, and physical characteristics of materials and thin films. The scattered intensity of an X-ray beam striking a sample is measured as a function of incident and scattered angle, polarization, and wavelength or energy.

One of these approaches, small-angle X-ray scattering (SAXS), examines supramolecular assemblages in the nanometer to micrometer range by measuring scattering intensity at scattering angles near to $0^{\circ}$. The molecular weight $\left(\mathrm{M}_{\mathrm{w}}\right)$, radius of gyration $\left(\mathrm{R}_{\mathrm{g}}\right)$, and maximum intramolecular distance $\left(\mathrm{D}_{\max }\right)$, as well as average particle size, shape, distribution, and surface-to-volume ratio, are traditionally measured using SAXS [173]. Colloids of various kinds, e.g., metals, cement, oil, polymers, plastics, proteins, foods, and medications are all studied using SAXS [174]. Because most supramolecular gels contain fiber-like structures linked by noncovalent interactions, SAXS is particularly effective for determining the form, size, and distribution of these fibers. The packing mode, on the other hand, may be deduced from SAXS data. Smith and colleagues described new one-component gelators made up of L-lysine-based dendritic headgroups of various generations (first to third) covalently attached to aliphatic diamine spacer chains of various lengths through an amide bond [175]. The fundamental driving factors leading the self-assembly process that support 
macroscopic gelation are intermolecular hydrogen bonds between the amide groups, with carbamates in the dendritic head groups playing a supporting or secondary role [176]. These gelators had a favorable dendritic effect, and the extra hydrogen bonds that higher generation systems could form had a big impact on the thermal characteristics of gels up to the third generation. SAXS may be used to evaluate a wide range of materials, as long as at least biphasic systems have been cultivated [177]. The extreme scattering intensities of the specimens are affected by variations in electron density in multiphase systems [178]. Due to their high surface energy, incorporating hydrophilic nanofillers into network-type design with high order of dispersion into the system is quite difficult. Surface interactions between clay platelets and hydrophilic groups of the polymer system during synthesis are influenced not only by their chemical characteristics, but also by the platelet surfaces geometry or morphology. The amount of the accessible surfaces is often attributed to the hydrophilic functions present in the hydrogel systems by surface morphology [179]. Using fractal geometry to characterize surface geometry or morphology is one technique to do so. It is usually measured in fractal dimensions, or D, which is a number that describes the irregularities or asperities on the surface of solid materials. When fractal geometry is used to interpret scattering from an organic-inorganic hybrid system, such as the composite hydrogel, it can simplify the process. SAXS may be used to assess ionic crosslinked hydrogels. The junction sites are more evident when alginate has been crosslinked by $\mathrm{Ca}^{2+}$ ions, according to the Guinier approximation, which was better assessed under a cross-sectioned system. The creation of an "egg-box" concept is proposed for ionic crosslinking among alginate strands. Another type of superabsorbent hydrogel is nanocomposite hydrogels using clay as reinforcement. Polyacrylate (PAA) and nanoclay have been homogeneously combined in this context to integrate their structures and characteristics [180]. As a result, in the case of ionotropic gelation, SAXS is critical for evaluating the network system, which has a direct impact on water uptake behavior. Instead of rheological behavior, SAXS may be compared to the flow characteristic. Higher elastic modulus, or gel strength, derives from a stiffer network (ratio of elastic to loss shear modulus) [181].

\section{Small-Angle Neutron Scattering (SANS)}

In many ways, SANS and SAXS are extremely similar. Small-angle scattering is the umbrella term for both approaches (SAS). A beam of neutrons is directed towards a sample in a SANS experiment, and the neutrons are elastically scattered by nuclear contact with nuclei or interaction with the magnetic moments of unpaired electrons, whereas photons interact with electron clouds in an X-ray scattering experiment [182]. The sensitivity to light elements, the potential of isotope labeling, and the intense scattering by magnetic moments are all advantages of SANS over SAXS. The neutron is a subatomic particle with 1839 times the mass of an electron $\left(1.674928 \times 10^{-27} \mathrm{~kg}\right)$, a magnetic moment of $-9.6491783 \times 10^{-27} \mathrm{~J} / \mathrm{T}$, and a lifespan of $15 \mathrm{~min}$. A neutron possesses both a particle and a wavelike nature, according to wave-particle duality. As a result of interacting with other particles/matter, it is prone to reflect, scatter, refract, and diffract. First, it should be noted that particle and neutron collisions occur in two ways during small-angle neutron scattering (SANS) experiments: nuclear scattering and interactions with unpaired electrons. The magnetic moment is increased as a result of interactions with unpaired electrons. Magnetic scattering is the term for this phenomenon. After particle-neutron collisions, the most prevalent assumption is that neutrons disperse elastically. The scattering of a neutron colliding with a nucleus is determined by the interaction potential between the neutron and the nucleus, which has a very limited domain $\left(10^{-15} \mathrm{~m}\right)$. SANS experiments are also known as scattering cross-section experiments. The scattering cross-section is a fictitious term that describes how "large" the nucleus appears to the incident neutron [183]. It is calculated as the ratio of neutron count after scattering to neutron flow per unit time. The particles present in a phase or the density differential between phases are the subject of SANS analysis. Contrast variation is another strategy for complicated systems in this context. 
Neutron-scattering study on PVA hydrogels is the most often used method. Because the degree of hydration of PVA influences crystallinity, there is a lot of anisotropy in this system. SANS is an excellent nondestructive approach for investigating the anisotropic feature of PVA gels, where structural changes are measured on a $100 \mathrm{~nm}$ scale [184].

\section{Spectroscopy}

The infrared part of the electromagnetic spectrum, which is light with a longer wavelength and lower frequency than visible light, is studied using infrared spectroscopy (IR) [185]. Infrared spectroscopy is a popular method in organic and inorganic chemistry, as well as in research and industry. It is commonly utilized in applications including quality control, dynamic measurements, and monitoring. Of course, infrared spectroscopy may be used to analyze the creation of supramolecular gels as it can reveal the assembly of molecular-sized building blocks and identify the noncovalent interactions that produce gelation.

Absorption or reflectance spectroscopy in the ultraviolet-visible spectral band is referred to as ultraviolet-visible spectroscopy (UV/Vis). Electronic transitions occur in this area of the electromagnetic spectrum. Because fluorescence spectroscopy deals with transitions from the excited state to the ground state, absorption spectroscopy deals with transitions from the ground state to the excited state. Molecules with $\pi$-electrons or nonbonding electrons (n-electrons) can absorb ultraviolet or visible light energy and excite these electrons to higher antibonding molecular orbitals. The narrower the energy difference between the HOMO and the LUMO, the easier it is for electrons to be excited, and the longer wavelength of light they absorb. Different analytes, such as transition metal ions, highly conjugated chemical compounds, and biological macromolecules, are frequently quantified using UV/Vis spectroscopy.

Another sort of electromagnetic spectroscopy is fluorescence spectroscopy, which studies fluorescence from a sample. For investigating organic substances, fluorescence spectroscopy is widely employed in biochemical, medicinal, and chemical research disciplines [186]. It entails utilizing a beam of light, generally ultraviolet light, to excite electrons and cause them to produce light, which is usually visible, but not always [187]. The species is first stimulated from its ground electronic state to one of the several vibrational modes in the excited electronic state in fluorescence spectroscopy by absorbing a photon. Collisions with other molecules cause the excited molecule to lose vibrational energy until it achieves the singlet excited electronic state's lowest vibrational state. A Jablonski diagram is frequently used to depict this procedure [188,189]. The molecule then returns to one of the ground electronic state's numerous vibrational states, accompanied by the emission of a photon. The released photons will have varying energy, or frequencies, when molecules drop down to one of several vibrational states in the ground state. As a result, the structures with distinct vibrational levels may be determined by analyzing the different frequencies of light emitted in fluorescence spectroscopy, as well as their relative intensities [190]. Carbon is typically thought of as a dark substance that was difficult to dissolve in water until recent study revealed that it has a high luminosity characteristic. However, only traditional bulk carbon was connected with the black substance, as its physical and chemical characteristics were radically altered when its size was lowered to the nanoscale scale, compared to the macroscopic material [191-193]. Buckminsterfullerene $\left(C_{60}\right)$ [193], graphene [194,195], CNTs [196], nanodiamonds [197-199], carbon nanofibers [200], and carbon dots (CDs) [201,202], which were recently found, are some of the most well-known carbon nanomaterials. The most recent type of nanocarbon, CDs, is stimulating extensive research efforts in its own right, similar to its well-known elder cousins such as fullerene, CNTs, and graphene. Xu et al. found CDs by chance during the purification of SWCNTs made from arc-discharge soot. The development in fluorescent hydrogel's physical characteristics is multifaceted. Mechanical, thermal, and optical qualities are the major characteristics that separate fluorescent hydrogels from one another. Hydrogels are typically a crosslinked polymer mass that is insoluble in solvents. These crosslinks might be chemical 
or physical in nature. When CDs are mixed into gels, however, two forms of crosslinking are visible: chemical and physical crosslinking. Chemical and physical crosslinking have been credited in hydrogels to increase their superior toughness, according to several studies. A $650 \%$ elongation PAAm and CD-based hydrogel has been reported elsewhere.

\section{Summary and Outlook}

Polymer composites have already been a popular area of research for several decades. The exceptional improvement in physical and chemical properties is synergistically improved for developing composite materials. Polymer hydrogels with different filler loadings show mechanical robustness and tunable swelling behaviors. Clay and graphene are both 2D materials used for preparing composite hydrogels. Clay-based hydrogels are showing water uptake behaviors and high strength, whereas graphene-reinforced composite hydrogels are good at electrical applications such as flexible electronics and deformation sensors. Very recently, graphene-based composite hydrogels have also been used as pulsatile drugrelease devices for iontophoretic release applications. Moreover, high strain tolerance is an added feature to graphene hydrogels by virtue of which can be used as strain sensors. Several cutting-edge robotics applications require flexibility and cyclic compressibility without any premature permanent set. In this aspect, 2D materials, such as clay and graphene, could serve as potential additives for mechanical property enhancement.

Author Contributions: Conceptualization, S.G. and S.M.; resources, S.G.; writing-original draft preparation, S.G and S.M. All authors have read and agreed to the published version of the manuscript.

Funding: This research received no external funding.

Conflicts of Interest: The authors declare no conflict of interest.

\section{References}

1. Sharma, S.; Tiwari, S. A review on biomacromolecular hydrogel classification and its applications. Int. J. Biol. Macromol. 2020, 162, 737-747. [CrossRef] [PubMed]

2. Zhang, A.; Liu, Y.; Qin, D.; Sun, M.; Wang, T.; Chen, X. Research status of self-healing hydrogel for wound management: A review. Int. J. Biol. Macromol. 2020, 164, 2108-2123. [CrossRef] [PubMed]

3. Ziv-Polat, O.; Skaat, H.; Shahar, A.; Margel, S. Novel magnetic fibrin hydrogel scaffolds containing thrombin and growth factors conjugated iron oxide nanoparticles for tissue engineering. Int. J. Nanomed. 2012, 7, 1259. [CrossRef]

4. Cascone, S.; Lamberti, G. Hydrogel-based commercial products for biomedical applications: A review. Int. J. Pharm. 2020, 573, 118803. [CrossRef] [PubMed]

5. Bai, H.; Li, C.; Wang, X.; Shi, G. A pH-sensitive graphene oxide composite hydrogel. Chem. Commun. 2010, 46, 2376-2378. [CrossRef]

6. Shah, R.; Gashi, B.; Hoque, S.; Marian, M.; Rosenkranz, A. Enhancing Mechanical and Biomedical Properties of Protheses-Surface and Material Design. Surf. Interfaces 2021, 27, 101498. [CrossRef]

7. Ganguly, S.; Das, P.; Itzhaki, E.; Hadad, E.; Gedanken, A.; Margel, S. Microwave-synthesized polysaccharide-derived carbon dots as therapeutic cargoes and toughening agents for elastomeric gels. ACS Appl. Mater. Interfaces 2020, 12, 51940-51951. [CrossRef]

8. Ganguly, S.; Das, P.; Das, N.C. Characterization tools and techniques of hydrogels. In Hydrogels Based on Natural Polymers; Elsevier: Amsterdam, The Netherlands, 2020; pp. 481-517.

9. Ganguly, S.; Maity, T.; Mondal, S.; Das, P.; Das, N.C. Starch functionalized biodegradable semi-IPN as a pH-tunable controlled release platform for memantine. Int. J. Biol. Macromol. 2017, 95, 185-198. [CrossRef] [PubMed]

10. Lee, J.-H.; Kim, H.-W. Emerging properties of hydrogels in tissue engineering. J. Tissue Eng. 2018, 9, 2041731418768285. [CrossRef]

11. Nicodemus, G.D.; Bryant, S.J. Cell encapsulation in biodegradable hydrogels for tissue engineering applications. Tissue Eng. Part B Rev. 2008, 14, 149-165. [CrossRef]

12. Hunt, J.A.; Chen, R.; van Veen, T.; Bryan, N. Hydrogels for tissue engineering and regenerative medicine. J. Mater. Chem. B 2014, 2, 5319-5338. [CrossRef]

13. Zhu, J. Bioactive modification of poly (ethylene glycol) hydrogels for tissue engineering. Biomaterials 2010, 31, 4639-4656. [CrossRef]

14. Skaat, H.; Ziv-Polat, O.; Shahar, A.; Last, D.; Mardor, Y.; Margel, S. Magnetic scaffolds enriched with bioactive nanoparticles for tissue engineering. Adv. Healthc. Mater. 2012, 1, 168-171. [CrossRef] [PubMed]

15. Ganguly, S.; Mondal, S.; Das, P.; Bhawal, P.; Maity, P.P.; Ghosh, S.; Dhara, S.; Das, N.C. Design of psyllium-g-poly (acrylic acid-co-sodium acrylate)/cloisite 10A semi-IPN nanocomposite hydrogel and its mechanical, rheological and controlled drug release behaviour. Int. J. Biol. Macromol. 2018, 111, 983-998. [CrossRef] [PubMed] 
16. Das, P.; Ganguly, S.; Margel, S.; Gedanken, A. Tailor made magnetic nanolights: Fabrication to cancer theranostics applications. Nanoscale Adv. 2021, 3, 6762-6796. [CrossRef]

17. Manandhar, P.; Calvert, P.D.; Buck, J.R. Elastomeric ionic hydrogel sensor for large strains. IEEE Sens. J. 2012, 12, 2052-2061. [CrossRef]

18. Bhat, A.; Amanor-Boadu, J.M.; Guiseppi-Elie, A. Toward impedimetric measurement of acidosis with a pH-responsive hydrogel sensor. ACS Sens. 2020, 5, 500-509. [CrossRef]

19. Richter, A.; Paschew, G.; Klatt, S.; Lienig, J.; Arndt, K.-F.; Adler, H.-J.P. Review on hydrogel-based pH sensors and microsensors Sensors 2008, 8, 561-581. [CrossRef]

20. Herber, S.; Olthuis, W.; Bergveld, P. A swelling hydrogel-based PCO2 sensor. Sens. Actuators B Chem. 2003, 91, 378-382. [CrossRef]

21. Salehi, A.A.; Ghannadi-Maragheh, M.; Torab-Mostaedi, M.; Torkaman, R.; Asadollahzadeh, M. Hydrogel materials as an emerging platform for desalination and the production of purified water. Sep. Purif. Rev. 2021, 50, 380-399. [CrossRef]

22. Amiri, S.; Asghari, A.; Vatanpour, V.; Rajabi, M. Fabrication and characterization of a novel polyvinyl alcohol-graphene oxidesodium alginate nanocomposite hydrogel blended PES nanofiltration membrane for improved water purification. Sep. Purif. Technol. 2020, 250, 117216. [CrossRef]

23. Thakur, S.; Sharma, B.; Verma, A.; Chaudhary, J.; Tamulevicius, S.; Thakur, V.K. Recent approaches in guar gum hydrogel synthesis for water purification. Int. J. Polym. Anal. Charact. 2018, 23, 621-632. [CrossRef]

24. Yazdi, M.K.; Vatanpour, V.; Taghizadeh, A.; Taghizadeh, M.; Ganjali, M.R.; Munir, M.T.; Habibzadeh, S.; Saeb, M.R.; Ghaedi, M. Hydrogel membranes: A review. Mater. Sci. Eng. C 2020, 114, 111023. [CrossRef] [PubMed]

25. Oveissi, F.; Fletcher, D.F.; Dehghani, F.; Naficy, S. Tough hydrogels for soft artificial muscles. Mater. Des. 2021, 203, 109609. [CrossRef]

26. Browe, D.P.; Wood, C.; Sze, M.T.; White, K.A.; Scott, T.; Olabisi, R.M.; Freeman, J.W. Characterization and optimization of actuating poly (ethylene glycol) diacrylate/acrylic acid hydrogels as artificial muscles. Polymer 2017, 117, 331-341. [CrossRef]

27. Sano, K.; Ishida, Y.; Aida, T. Synthesis of anisotropic hydrogels and their applications. Angew. Chem. Int. Ed. 2018, 57, 2532-2543. [CrossRef]

28. Bassil, M.; Ibrahim, M.; El Tahchi, M. Artificial muscular microfibers: Hydrogel with high speed tunable electroactivity. Soft Matter 2011, 7, 4833-4838. [CrossRef]

29. Appiah, C.; Arndt, C.; Siemsen, K.; Heitmann, A.; Staubitz, A.; Selhuber-Unkel, C. Living materials herald a new era in soft robotics. Adv. Mater. 2019, 31, 1807747. [CrossRef] [PubMed]

30. Vallittu, P.K. High-aspect ratio fillers: Fiber-reinforced composites and their anisotropic properties. Dent. Mater. 2015, 31, 1-7. [CrossRef]

31. Ganguly, S. Preparation/processing of polymer-graphene composites by different techniques. In Polymer Nanocomposites Containing Graphene; Elsevier: Amsterdam, The Netherlands, 2022; pp. 45-74. [CrossRef]

32. Pacelli, S.; Rampetsreiter, K.; Modaresi, S.; Subham, S.; Chakravarti, A.R.; Lohfeld, S.; Detamore, M.S.; Paul, A. Fabrication of a double-cross-linked interpenetrating polymeric network (IPN) hydrogel surface modified with polydopamine to modulate the osteogenic differentiation of adipose-derived stem cells. ACS Appl. Mater. Interfaces 2018, 10, 24955-24962. [CrossRef] [PubMed]

33. Suzuki, K.; Saito, Y.; Tokuoka, Y.; Abe, M.; Sato, T. Poly (ethylene oxide)/poly (propylene oxide)/poly (ethylene oxide) triblock copolymer as a sustained-release carrier for perfume compounds. J. Am. Oil Chem. Soc. 1997, 74, 55-59. [CrossRef]

34. Vadnere, M.; Amidon, G.; Lindenbaum, S.; Haslam, J.L. Thermodynamic studies on the gel-sol transition of some pluronic polyols. Int. J. Pharm. 1984, 22, 207-218. [CrossRef]

35. Jeong, B.; Kibbey, M.R.; Birnbaum, J.C.; Won, Y.-Y.; Gutowska, A. Thermogelling biodegradable polymers with hydrophilic backbones: PEG-g-PLGA. Macromolecules 2000, 33, 8317-8322. [CrossRef]

36. Vernon, B.; Gutowska, A.; Wan Kim, S.; Han Bae, Y. Thermally reversible polymer gels for biohybrid artificial pancreas. In Proceedings of the Macromolecular Symposia; 1996; pp. 155-167.

37. Gutowska, A.; Jeong, B.; Jasionowski, M. Injectable gels for tissue engineering. Anat. Rec. Off. Publ. Am. Assoc. Anat. 2001, 263, 342-349. [CrossRef] [PubMed]

38. Sivashanmugam, A.; Kumar, R.A.; Priya, M.V.; Nair, S.V.; Jayakumar, R. An overview of injectable polymeric hydrogels for tissue engineering. Eur. Polym. J. 2015, 72, 543-565. [CrossRef]

39. Galperin, A.; Long, T.J.; Ratner, B.D. Degradable, thermo-sensitive poly (N-isopropyl acrylamide)-based scaffolds with controlled porosity for tissue engineering applications. Biomacromolecules 2010, 11, 2583-2592. [CrossRef] [PubMed]

40. Qureshi, D.; Nayak, S.K.; Maji, S.; Anis, A.; Kim, D.; Pal, K. Environment sensitive hydrogels for drug delivery applications. Eur. Polym. J. 2019, 120, 109220. [CrossRef]

41. Bai, X.; Lü, S.; Cao, Z.; Gao, C.; Duan, H.; Xu, X.; Sun, L.; Gao, N.; Feng, C.; Liu, M. Self-reinforcing injectable hydrogel with both high water content and mechanical strength for bone repair. Chem. Eng. J. 2016, 288, 546-556. [CrossRef]

42. Ribeiro, C.A.; Martins, M.V.S.; Bressiani, A.H.; Bressiani, J.C.; Leyva, M.E.; de Queiroz, A.A.A. Electrochemical preparation and characterization of PNIPAM-HAp scaffolds for bone tissue engineering. Mater. Sci. Eng. C 2017, 81, 156-166. [CrossRef]

43. Liu, J.; Jiang, L.; He, S.; Zhang, J.; Shao, W. Recent progress in PNIPAM-based multi-responsive actuators: A mini-review. Chem. Eng. J. 2021, 133496. [CrossRef]

44. Ayar, Z.; Shafieian, M.; Mahmoodi, N.; Sabzevari, O.; Hassannejad, Z. A rechargeable drug delivery system based on pNIPAM hydrogel for the local release of curcumin. J. Appl. Polym. Sci. 2021, 138, 51167. [CrossRef] 
45. Zheng, H.; Zhang, S.; Yang, C.; Yin, H.; Liu, W.; Lu, K. Simultaneous removal of Ni (II) and Cr (VI) from aqueous solution by froth flotation using PNIPAM-CS intelligent nano-hydrogels as collector. J. Mol. Liq. 2021, 342, 117551. [CrossRef]

46. Saikia, A.; Aggarwal, S.; Mandal, U. Preparation and controlled drug release characteristics of thermoresponsive PEG/poly (NIPAM-co-AMPS) hydrogels. Int. J. Polym. Mater. 2013, 62, 39-44. [CrossRef]

47. Ganguly, S.; Das, P.; Das, T.K.; Ghosh, S.; Das, S.; Bose, M.; Mondal, M.; Das, A.K.; Das, N.C. Acoustic cavitation assisted destratified clay tactoid reinforced in situ elastomer-mimetic semi-IPN hydrogel for catalytic and bactericidal application. Ultrason. Sonochem. 2020, 60, 104797. [CrossRef]

48. Takeno, H.; Aoki, Y.; Kimura, K. Effects of Silica and Clay Nanoparticles on the Mechanical Properties of Poly (vinyl alcohol) Nanocomposite Hydrogels. Colloids Surf. A Physicochem. Eng. Asp. 2021, 630, 127592. [CrossRef]

49. Wang, Y.-T.; Zhao, H.-B.; Degracia, K.; Han, L.-X.; Sun, H.; Sun, M.; Wang, Y.-Z.; Schiraldi, D.A. Green approach to improving the strength and flame retardancy of poly (vinyl alcohol)/clay aerogels: Incorporating biobased gelatin. ACS Appl. Mater. Interfaces 2017, 9, 42258-42265. [CrossRef]

50. Ganguly, S.; Margel, S. Remotely controlled magneto-regulation of therapeutics from magnetoelastic gel matrices. Biotechnol. Adv. 2020, 107611. [CrossRef]

51. Yang, W.; Qi, G.; Kenny, J.M.; Puglia, D.; Ma, P. Effect of cellulose nanocrystals and lignin nanoparticles on mechanical, antioxidant and water vapour barrier properties of glutaraldehyde crosslinked PVA films. Polymers 2020, 12, 1364. [CrossRef]

52. Clark, A.H.; Ross-Murphy, S.B. The concentration dependence of biopolymer gel modulus. Br. Polym. J. 1985, 17, 164-168. [CrossRef]

53. Ganguly, S.; Grinberg, I.; Margel, S. Layer by layer controlled synthesis at room temperature of tri-modal (MRI, fluorescence and CT) core/shell superparamagnetic IO/human serum albumin nanoparticles for diagnostic applications. Polym. Adv. Technol. 2021, 32, 3909-3921. [CrossRef]

54. Ganguly, S.; Das, N.C. Water uptake kinetics and control release of agrochemical fertilizers from nanoclay-assisted semiinterpenetrating sodium acrylate-based hydrogel. Polym. Plast. Technol. Eng. 2017, 56, 744-761. [CrossRef]

55. Saha, K.; Dutta, K.; Basu, A.; Adhikari, A.; Chattopadhyay, D.; Sarkar, P. Controlled delivery of tetracycline hydrochloride intercalated into smectite clay using polyurethane nanofibrous membrane for wound healing application. Nano-Struct. NanoObjects 2020, 21, 100418. [CrossRef]

56. Haraguchi, K.; Farnworth, R.; Ohbayashi, A.; Takehisa, T. Compositional effects on mechanical properties of nanocomposite hydrogels composed of poly (N, N-dimethylacrylamide) and clay. Macromolecules 2003, 36, 5732-5741. [CrossRef]

57. Okay, O.; Oppermann, W. Polyacrylamide-clay nanocomposite hydrogels: Rheological and light scattering characterization. Macromolecules 2007, 40, 3378-3387. [CrossRef]

58. Kamoun, E.A.; Menzel, H. HES-HEMA nanocomposite polymer hydrogels: Swelling behavior and characterization. J. Polym. Res. 2012, 19, 1-14. [CrossRef]

59. Kaşgöz, H.; Durmus, A. Dye removal by a novel hydrogel-clay nanocomposite with enhanced swelling properties. Polym. Adv. Technol. 2008, 19, 838-845. [CrossRef]

60. Zhang, J.; Yuan, K.; Wang, Y.-P.; Gu, S.-J.; Zhang, S.-T. Preparation and properties of polyacrylate/bentonite superabsorbent hybrid via intercalated polymerization. Mater. Lett. 2007, 61, 316-320. [CrossRef]

61. Wang, L.; Zhang, J.; Wang, A. Removal of methylene blue from aqueous solution using chitosan-g-poly (acrylic acid)/montmorillonite superadsorbent nanocomposite. Colloids Surf. A Physicochem. Eng. Asp. 2008, 322, 47-53. [CrossRef]

62. Kaşgöz, H.; Durmuş, A.; Kaşgöz, A. Enhanced swelling and adsorption properties of AAm-AMPSNa/clay hydrogel nanocomposites for heavy metal ion removal. Polym. Adv. Technol. 2008, 19, 213-220. [CrossRef]

63. Liu, P.S.; Li, L.; Zhou, N.L.; Zhang, J.; Wei, S.H.; Shen, J. Waste polystyrene foam-graft-acrylic acid/montmorillonite superabsorbent nanocomposite. J. Appl. Polym. Sci. 2007, 104, 2341-2349. [CrossRef]

64. Liu, P.S.; Li, L.; Zhou, N.L.; Zhang, J.; Wei, S.H.; Shen, J. Synthesis and properties of a poly (acrylic acid)/montmorillonite superabsorbent nanocomposite. J. Appl. Polym. Sci. 2006, 102, 5725-5730. [CrossRef]

65. Ganguly, S.; Das, N.C. Synthesis of a novel pH responsive phyllosilicate loaded polymeric hydrogel based on poly (acrylic acid-co-N-vinylpyrrolidone) and polyethylene glycol for drug delivery: Modelling and kinetics study for the sustained release of an antibiotic drug. RSC Adv. 2015, 5, 18312-18327. [CrossRef]

66. Wang, J.; Wang, W.; Wang, A. Synthesis, characterization and swelling behaviors of hydroxyethyl cellulose-g-poly (acrylic acid)/attapulgite superabsorbent composite. Polym. Eng. Sci. 2010, 50, 1019-1027. [CrossRef]

67. Al, E.; Güçlü, G.; İyim, T.B.; Emik, S.; Özgümüş, S. Synthesis and properties of starch-graft-acrylic acid/Na-montmorillonite superabsorbent nanocomposite hydrogels. J. Appl. Polym. Sci. 2008, 109, 16-22. [CrossRef]

68. Xu, K.; Wang, J.; Xiang, S.; Chen, Q.; Yue, Y.; Su, X.; Song, C.; Wang, P. Polyampholytes superabsorbent nanocomposites with excellent gel strength. Compos. Sci. Technol. 2007, 67, 3480-3486. [CrossRef]

69. Qiu, H.; Yu, J. Polyacrylate/(carboxymethylcellulose modified montmorillonite) superabsorbent nanocomposite: Preparation and water absorbency. J. Appl. Polym. Sci. 2008, 107, 118-123. [CrossRef]

70. Zhang, J.; Wang, L.; Wang, A. Preparation and properties of chitosan-g-poly (acrylic acid)/montmorillonite superabsorbent nanocomposite via in situ intercalative polymerization. Ind. Eng. Chem. Res. 2007, 46, 2497. [CrossRef]

71. Santiago, F.; Mucientes, A.E.; Osorio, M.; Poblete, F.J. Synthesis and swelling behaviour of poly (sodium acrylate)/sepiolite superabsorbent composites and nanocomposites. Polym. Int. 2006, 55, 843-848. [CrossRef] 
72. Lee, W.F.; Yang, L.G. Superabsorbent polymeric materials. XII. Effect of montmorillonite on water absorbency for poly (sodium acrylate) and montmorillonite nanocomposite superabsorbents. J. Appl. Polym. Sci. 2004, 92, 3422-3429. [CrossRef]

73. Zhang, H.; Yu, J.; Wang, H.; Xue, L. Investigation of microstructures and ultraviolet aging properties of organomontmorillonite/SBS modified bitumen. Mater. Chem. Phys. 2011, 129, 769-776. [CrossRef]

74. Zheng, Y.; Gao, T.; Wang, A. Preparation, swelling, and slow-release characteristics of superabsorbent composite containing sodium humate. Ind. Eng. Chem. Res. 2008, 47, 1766-1773. [CrossRef]

75. Zhang, J.; Li, A.; Wang, A. Synthesis and characterization of multifunctional poly (acrylic acid-co-acrylamide)/sodium humate superabsorbent composite. React. Funct. Polym. 2006, 66, 747-756. [CrossRef]

76. Xie, Y.; Wu, J.; Lin, J.; Wei, Y.; Zhong, J. A conductive hydrogel by poly (sodium acrylate)/montmorillonite superabsorbent composite. Polym. Polym. Compos. 2007, 15, 29-33. [CrossRef]

77. Zhang, Y.; Fan, L.; Zhao, P.; Zhang, L.; Chen, H. Preparation of nanocomposite superabsorbents based on hydrotalcite and poly (acrylic-co-acrylamide) by inverse suspension polymerization. Compos. Interfaces 2008, 15, 747-757. [CrossRef]

78. Zheng, Y.; Wang, A. Study on superabsorbent composites. XVIII. Preparation, characterization, and property evaluation of poly (acrylic acid-co-acrylamide)/organomontmorillonite/sodium humate superabsorbent composites. J. Appl. Polym. Sci. 2008, 108, 211-219. [CrossRef]

79. Lee, W.F.; Chen, Y.C. Preparation of reactive mineral powders used for poly (sodium acrylate) composite superabsorbents. J. Appl. Polym. Sci. 2005, 97, 855-861. [CrossRef]

80. Zhang, Y.; Fan, L.; Cheng, L.; Zhang, L.; Chen, H. Preparation and morphology of high-performance exfoliated poly (sodium acrylate)/hydrotalcite nanocomposite superabsorbents. Polym. Eng. Sci. 2009, 49, 264-271. [CrossRef]

81. Wang, W.; Wang, A. Preparation, characterization and properties of superabsorbent nanocomposites based on natural guar gum and modified rectorite. Carbohydr. Polym. 2009, 77, 891-897. [CrossRef]

82. Wang, W.; Zhang, J.; Wang, A. Preparation and swelling properties of superabsorbent nanocomposites based on natural guar gum and organo-vermiculite. Appl. Clay Sci. 2009, 46, 21-26. [CrossRef]

83. Wang, W.; Wang, A. Preparation, swelling, and stimuli-responsive characteristics of superabsorbent nanocomposites based on carboxymethyl cellulose and rectorite. Polym. Adv. Technol. 2011, 22, 1602-1611. [CrossRef]

84. Huang, X.; Xu, S.; Zhong, M.; Wang, J.; Feng, S.; Shi, R. Modification of Na-bentonite by polycations for fabrication of amphoteric semi-IPN nanocomposite hydrogels. Appl. Clay Sci. 2009, 42, 455-459. [CrossRef]

85. Li, P.; Kim, N.H.; Lee, J.H. Swelling behavior of polyacrylamide/laponite clay nanocomposite hydrogels: $\mathrm{pH}$-sensitive property. Compos. Part B Eng. 2009, 40, 275-283. [CrossRef]

86. Qi, X.; Liu, M.; Chen, Z.; Liang, R. Preparation and properties of diatomite composite superabsorbent. Polym. Adv. Technol. 2007, 18, 184-193. [CrossRef]

87. Luo, W.; Zhang, W.A.; Chen, P.; Fang, Y.e. Synthesis and properties of starch grafted poly [acrylamide-co-(acrylic acid)]/montmorillonite nanosuperabsorbent via $\gamma$-ray irradiation technique. J. Appl. Polym. Sci. 2005, 96, 1341-1346. [CrossRef]

88. Seki, Y.; Torgürsül, A.; Yurdakoc, K. Preparation and characterization of poly (acrylic acid)-iron rich smectite superabsorbent composites. Polym. Adv. Technol. 2007, 18, 477-482. [CrossRef]

89. Liu, J.; Wang, Q.; Wang, A. Synthesis and characterization of chitosan-g-poly (acrylic acid)/sodium humate superabsorbent. Carbohydr. Polym. 2007, 70, 166-173. [CrossRef]

90. Tao, W.; Xiaoqing, W.; Yi, Y.; Wenqiong, H. Preparation of bentonite-poly [(acrylic acid)-acrylamide] water superabsorbent by photopolymerization. Polym. Int. 2006, 55, 1413-1419. [CrossRef]

91. Pourjavadi, A.; Ayyari, M.; Amini-Fazl, M. Taguchi optimized synthesis of collagen-g-poly (acrylic acid)/kaolin composite superabsorbent hydrogel. Eur. Polym. J. 2008, 44, 1209-1216. [CrossRef]

92. Hua, S.; Wang, A. Synthesis, characterization and swelling behaviors of sodium alginate-g-poly (acrylic acid)/sodium humate superabsorbent. Carbohydr. Polym. 2009, 75, 79-84. [CrossRef]

93. Ganguly, S.; Kanovsky, N.; Das, P.; Gedanken, A.; Margel, S. Photopolymerized Thin Coating of Polypyrrole/Graphene Nanofiber/Iron Oxide onto Nonpolar Plastic for Flexible Electromagnetic Radiation Shielding, Strain Sensing, and Non-Contact Heating Applications. Adv. Mater. Interfaces 2021, 8, 2101255. [CrossRef]

94. Das, P.; Ganguly, S.; Saha, A.; Noked, M.; Margel, S.; Gedanken, A. Carbon-dots-initiated photopolymerization: An in situ synthetic approach for MXene/poly (norepinephrine)/copper hybrid and its application for mitigating water pollution. ACS Appl. Mater. Interfaces 2021, 13, 31038-31050. [CrossRef]

95. Ganguly, S.; Margel, S. Design of Magnetic Hydrogels for Hyperthermia and Drug Delivery. Polymers 2021, 13, 4259. [CrossRef]

96. Adhikari, B.; Biswas, A.; Banerjee, A. Graphene oxide-based hydrogels to make metal nanoparticle-containing reduced graphene oxide-based functional hybrid hydrogels. ACS Appl. Mater. Interfaces 2012, 4, 5472-5482. [CrossRef]

97. Zhang, X.; Sui, Z.; Xu, B.; Yue, S.; Luo, Y.; Zhan, W.; Liu, B. Mechanically strong and highly conductive graphene aerogel and its use as electrodes for electrochemical power sources. J. Mater. Chem. 2011, 21, 6494-6497. [CrossRef]

98. Huang, H.; Lü, S.; Zhang, X.; Shao, Z. Glucono- $\delta$-lactone controlled assembly of graphene oxide hydrogels with selectively reversible gel-sol transition. Soft Matter 2012, 8, 4609-4615. [CrossRef]

99. Zu, S.-Z.; Han, B.-H. Aqueous dispersion of graphene sheets stabilized by pluronic copolymers: Formation of supramolecular hydrogel. J. Phys. Chem. C 2009, 113, 13651-13657. [CrossRef] 
100. Sahu, A.; Choi, W.I.; Tae, G. A stimuli-sensitive injectable graphene oxide composite hydrogel. Chem. Commun. 2012, 48, 5820-5822. [CrossRef] [PubMed]

101. Bardajee, G.R.; Hooshyar, Z. Drug release study by a novel thermo sensitive nanogel based on salep modified graphene oxide. J. Polym. Res. 2017, 24, 1-8. [CrossRef]

102. Zhang, N.; Li, R.; Zhang, L.; Chen, H.; Wang, W.; Liu, Y.; Wu, T.; Wang, X.; Wang, W.; Li, Y. Actuator materials based on graphene oxide/polyacrylamide composite hydrogels prepared by in situ polymerization. Soft Matter 2011, 7, 7231-7239. [CrossRef]

103. Si, H.; Luo, H.; Xiong, G.; Yang, Z.; Raman, S.R.; Guo, R.; Wan, Y. One-step in situ biosynthesis of graphene oxide-bacterial cellulose nanocomposite hydrogels. Macromol. Rapid Commun. 2014, 35, 1706-1711. [CrossRef]

104. Yu, Y.; Shu, Y.; Ye, L. In situ crosslinking of poly (vinyl alcohol)/graphene oxide-glutamic acid nano-composite hydrogel as microbial carrier: Intercalation structure and its wastewater treatment performance. Chem. Eng. J. 2018, 336, 306-314. [CrossRef]

105. Chen, P.; Wang, X.; Wang, G.; Duo, Y.; Zhang, X.; Hu, X.; Zhang, X. Double network self-healing graphene hydrogel by two step method for anticancer drug delivery. Mater. Technol. 2014, 29, 210-213. [CrossRef]

106. Zhang, H.; Zhai, D.; He, Y. Graphene oxide/polyacrylamide/carboxymethyl cellulose sodium nanocomposite hydrogel with enhanced mechanical strength: Preparation, characterization and the swelling behavior. RSC Adv. 2014, 4, 44600-44609. [CrossRef]

107. Ganguly, S.; Mondal, S.; Das, P.; Bhawal, P.; kanti Das, T.; Bose, M.; Choudhary, S.; Gangopadhyay, S.; Das, A.K.; Das, N.C. Natural saponin stabilized nano-catalyst as efficient dye-degradation catalyst. Nano-Struct. Nano-Objects 2018, 16, 86-95. [CrossRef]

108. Ganguly, S.; Das, P.; Maity, P.P.; Mondal, S.; Ghosh, S.; Dhara, S.; Das, N.C. Green reduced graphene oxide toughened semi-IPN monolith hydrogel as dual responsive drug release system: Rheological, physicomechanical, and electrical evaluations. J. Phys. Chem. B 2018, 122, 7201-7218. [CrossRef]

109. Das, P.; Ganguly, S.; Margel, S.; Gedanken, A. Immobilization of Heteroatom-Doped Carbon Dots onto Nonpolar Plastics for Antifogging, Antioxidant, and Food Monitoring Applications. Langmuir 2021, 37, 3508-3520. [CrossRef]

110. Tang, Z.; Gao, L.; Wu, Y.; Su, T.; Wu, Q.; Liu, X.; Li, W.; Wang, Q. BSA-rGO nanocomposite hydrogel formed by UV polymerization and in situ reduction applied as biosensor electrode. J. Mater. Chem. B 2013, 1, 5393-5397. [CrossRef]

111. Jiao, T.; Guo, H.; Zhang, Q.; Peng, Q.; Tang, Y.; Yan, X.; Li, B. Reduced graphene oxide-based silver nanoparticle-containing composite hydrogel as highly efficient dye catalysts for wastewater treatment. Sci. Rep. 2015, 5, 1-12. [CrossRef] [PubMed]

112. Raafat, A.I.; Ali, A.E.-H. pH-controlled drug release of radiation synthesized graphene oxide/(acrylic acid-co-sodium alginate) interpenetrating network. Polym. Bull. 2017, 74, 2045-2062. [CrossRef]

113. Dai, Z.; Lu, Q.; Quan, Q.; Mo, R.; Zhou, C.; Hong, P.; Li, C. Novel low temperature $\left(<37^{\circ} \mathrm{C}\right)$ chitosan hydrogel fabrication under the synergistic effect of graphene oxide. New J. Chem. 2017, 41, 671-676.

114. Lee, Y.; Bae, J.W.; Thi, T.T.H.; Park, K.M.; Park, K.D. Injectable and mechanically robust 4-arm PPO-PEO/graphene oxide composite hydrogels for biomedical applications. Chem. Commun. 2015, 51, 8876-8879. [CrossRef]

115. Yang, H.; Bremner, D.H.; Tao, L.; Li, H.; Hu, J.; Zhu, L. Carboxymethyl chitosan-mediated synthesis of hyaluronic acid-targeted graphene oxide for cancer drug delivery. Carbohydr. Polym. 2016, 135, 72-78. [CrossRef] [PubMed]

116. Xu, Z.; Wang, S.; Li, Y.; Wang, M.; Shi, P.; Huang, X. Covalent functionalization of graphene oxide with biocompatible poly (ethylene glycol) for delivery of paclitaxel. ACS Appl. Mater. Interfaces 2014, 6, 17268-17276. [CrossRef]

117. Wu, T.; Zhang, B.; Liang, Y.; Liu, T.; Bu, J.; Lin, L.; Wu, Z.; Liu, H.; Wen, S.; Tan, S. Heparin-modified graphene oxide loading anti-cancer drug and growth factor with heat stability, long-term release property and lower cytotoxicity. RSC Adv. 2015, 5, 84334-84342. [CrossRef]

118. Liu, R.; Liang, S.; Tang, X.-Z.; Yan, D.; Li, X.; Yu, Z.-Z. Tough and highly stretchable graphene oxide/polyacrylamide nanocomposite hydrogels. J. Mater. Chem. 2012, 22, 14160-14167. [CrossRef]

119. Zhong, M.; Liu, Y.-T.; Xie, X.-M. Self-healable, super tough graphene oxide-poly (acrylic acid) nanocomposite hydrogels facilitated by dual cross-linking effects through dynamic ionic interactions. J. Mater. Chem. B 2015, 3, 4001-4008. [CrossRef] [PubMed]

120. Yang, C.; Liu, Z.; Chen, C.; Shi, K.; Zhang, L.; Ju, X.-J.; Wang, W.; Xie, R.; Chu, L.-Y. Reduced graphene oxide-containing smart hydrogels with excellent electro-response and mechanical properties for soft actuators. ACS Appl. Mater. Interfaces 2017, 9, 15758-15767. [CrossRef]

121. Alam, A.; Meng, Q.; Shi, G.; Arabi, S.; Ma, J.; Zhao, N.; Kuan, H.-C. Electrically conductive, mechanically robust, pH-sensitive graphene/polymer composite hydrogels. Compos. Sci. Technol. 2016, 127, 119-126. [CrossRef]

122. Alam, A.; Kuan, H.-C.; Zhao, Z.; Xu, J.; Ma, J. Novel polyacrylamide hydrogels by highly conductive, water-processable graphene. Compos. Part A Appl. Sci. Manuf. 2017, 93, 1-9. [CrossRef]

123. Das, S.; Irin, F.; Ma, L.; Bhattacharia, S.K.; Hedden, R.C.; Green, M.J. Rheology and morphology of pristine graphene/polyacrylamide gels. ACS Appl. Mater. Interfaces 2013, 5, 8633-8640. [CrossRef] [PubMed]

124. Shen, J.; Yan, B.; Li, T.; Long, Y.; Li, N.; Ye, M. Mechanical, thermal and swelling properties of poly (acrylic acid)-graphene oxide composite hydrogels. Soft Matter 2012, 8, 1831-1836. [CrossRef]

125. Abdollahi, R.; Taghizadeh, M.T.; Savani, S. Thermal and mechanical properties of graphene oxide nanocomposite hydrogel based on poly (acrylic acid) grafted onto amylose. Polym. Degrad. Stab. 2018, 147, 151-158. [CrossRef]

126. Ganguly, S.; Ray, D.; Das, P.; Maity, P.P.; Mondal, S.; Aswal, V.; Dhara, S.; Das, N.C. Mechanically robust dual responsive water dispersible-graphene based conductive elastomeric hydrogel for tunable pulsatile drug release. Ultrason. Sonochem. 2018, 42, 212-227. [CrossRef] [PubMed] 
127. Dong, C.; Lu, J.; Qiu, B.; Shen, B.; Xing, M.; Zhang, J. Developing stretchable and graphene-oxide-based hydrogel for the removal of organic pollutants and metal ions. Appl. Catal. B Environ. 2018, 222, 146-156. [CrossRef]

128. Meng, Y.; Ye, L.; Coates, P.; Twigg, P. In situ cross-linking of poly (vinyl alcohol)/graphene oxide-polyethylene glycol nanocomposite hydrogels as artificial cartilage replacement: Intercalation structure, unconfined compressive behavior, and biotribological behaviors. J. Phys. Chem. C 2018, 122, 3157-3167. [CrossRef]

129. Faghihi, S.; Karimi, A.; Jamadi, M.; Imani, R.; Salarian, R. Graphene oxide/poly (acrylic acid)/gelatin nanocomposite hydrogel: Experimental and numerical validation of hyperelastic model. Mater. Sci. Eng. C 2014, 38, 299-305. [CrossRef]

130. Lee, S.; Lee, H.; Sim, J.H.; Sohn, D. Graphene oxide/poly (acrylic acid) hydrogel by $\gamma$-ray pre-irradiation on graphene oxide surface. Macromol. Res. 2014, 22, 165-172. [CrossRef]

131. Maeda, H. Anion-responsive supramolecular gels. Chem. A Eur. J. 2008, 14, 11274-11282. [CrossRef]

132. Lloyd, G.O.; Steed, J.W. Anion-tuning of supramolecular gel properties. Nat. Chem. 2009, 1, 437-442. [CrossRef]

133. Banerjee, S.; Das, R.K.; Maitra, U. Supramolecular gels 'in action'. J. Mater. Chem. 2009, 19, 6649-6687. [CrossRef]

134. Steed, J.W. Anion-tuned supramolecular gels: A natural evolution from urea supramolecular chemistry. Chem. Soc. Rev. 2010, 39, 3686-3699. [CrossRef]

135. Noro, A.; Hayashi, M.; Matsushita, Y. Design and properties of supramolecular polymer gels. Soft Matter 2012, 8, 6416-6429. [CrossRef]

136. Seiffert, S.; Sprakel, J. Physical chemistry of supramolecular polymer networks. Chem. Soc. Rev. 2012, 41, 909-930. [CrossRef] [PubMed]

137. Foster, J.A.; Steed, J.W. Exploiting cavities in supramolecular gels. Angew. Chem. Int. Ed. 2010, 49, 6718-6724. [CrossRef]

138. Steed, J.W. Supramolecular gel chemistry: Developments over the last decade. Chem. Commun. 2011, 47, 1379-1383. [CrossRef]

139. Appel, E.A.; del Barrio, J.; Loh, X.J.; Scherman, O.A. Supramolecular polymeric hydrogels. Chem. Soc. Rev. 2012, 41, 6195-6214. [CrossRef] [PubMed]

140. Buerkle, L.E.; Rowan, S.J. Supramolecular gels formed from multi-component low molecular weight species. Chem. Soc. Rev. 2012, 41, 6089-6102. [CrossRef] [PubMed]

141. Samanta, S.K.; Pal, A.; Bhattacharya, S.; Rao, C. Carbon nanotube reinforced supramolecular gels with electrically conducting, viscoelastic and near-infrared sensitive properties. J. Mater. Chem. 2010, 20, 6881-6890. [CrossRef]

142. Abdallah, D.J.; Sirchio, S.A.; Weiss, R.G. Hexatriacontane organogels. The first determination of the conformation and molecular packing of a low-molecular-mass organogelator in its gelled state. Langmuir 2000, 16, 7558-7561. [CrossRef]

143. Echegoyen, L.E.; Portugal, L.; Miller, S.R.; Hernandez, J.C.; Echegoyen, L.; Gokel, G.W. The first evidence for aggregation behavior in a lipophilic [2.2. 2]-cryptand and in 18-membered ring steroidal lariat ethers. Tetrahedron Lett. 1988, 29, 4065-4068. [CrossRef]

144. Hirst, A.R.; Smith, D.K.; Harrington, J.P. Unique Nanoscale Morphologies Underpinning Organic Gel-Phase Materials. Chem. A Eur. J. 2005, 11, 6552-6559. [CrossRef] [PubMed]

145. ávan Esch, J.H. Dynamic covalent assembly of stimuli responsive vesicle gels. Chem. Commun. 2012, 48, 9837-9839.

146. Harada, A.; Kobayashi, R.; Takashima, Y.; Hashidzume, A.; Yamaguchi, H. Macroscopic self-assembly through molecular recognition. Nat. Chem. 2011, 3, 34-37. [CrossRef] [PubMed]

147. Park, T.; Zimmerman, S.C. Formation of a miscible supramolecular polymer blend through self-assembly mediated by a quadruply hydrogen-bonded heterocomplex. J. Am. Chem. Soc. 2006, 128, 11582-11590. [CrossRef]

148. Shirakawa, M.; Fujita, N.; Shinkai, S. [60] Fullerene-motivated organogel formation in a porphyrin derivative bearing programmed hydrogen-bonding sites. J. Am. Chem. Soc. 2003, 125, 9902-9903. [CrossRef] [PubMed]

149. Moffat, J.R.; Seeley, G.J.; Carter, J.T.; Burgess, A.; Smith, D.K. Nanostructured polymers with embedded self-assembled reactive gel networks. Chem. Commun. 2008, 4601-4603. [CrossRef] [PubMed]

150. Ge, Z.; Hu, J.; Huang, F.; Liu, S. Responsive supramolecular gels constructed by crown ether based molecular recognition. Angew. Chem. 2009, 121, 1830-1834. [CrossRef]

151. Deng, C.; Fang, R.; Guan, Y.; Jiang, J.; Lin, C.; Wang, L. Sonication-induced self-assembly of flexible tris (ureidobenzyl) amine: From dimeric aggregates to supramolecular gels. Chem. Commun. 2012, 48, 7973-7975. [CrossRef]

152. Liu, Q.; Wang, Y.; Li, W.; Wu, L. Structural characterization and chemical response of a Ag-coordinated supramolecular gel. Langmuir 2007, 23, 8217-8223. [CrossRef] [PubMed]

153. Liu, J.-W.; Yang, Y.; Chen, C.-F.; Ma, J.-T. Novel anion-tuning supramolecular gels with dual-channel response: Reversible solgel transition and color changes. Langmuir 2010, 26, 9040-9044. [CrossRef]

154. Das, R.N.; Kumar, Y.P.; Pagoti, S.; Patil, A.J.; Dash, J. Diffusion and birefringence of bioactive dyes in a supramolecular guanosine hydrogel. Chem. A Eur. J. 2012, 18, 6008-6014. [CrossRef]

155. Huang, F.; Switek, K.A.; Zakharov, L.N.; Fronczek, F.R.; Slebodnick, C.; Lam, M.; Golen, J.A.; Bryant, W.S.; Mason, P.E.; Rheingold, A.L. Bis (m-phenylene)-32-crown-10-based cryptands, powerful hosts for paraquat derivatives. J. Org. Chem. 2005, 70, 3231-3241. [CrossRef]

156. Yan, X.; Xu, D.; Chi, X.; Chen, J.; Dong, S.; Ding, X.; Yu, Y.; Huang, F. A multiresponsive, shape-persistent, and elastic supramolecular polymer network gel constructed by orthogonal self-assembly. Adv. Mater. 2012, 24, 362-369. [CrossRef] [PubMed]

157. Xiao, T.; Feng, X.; Ye, S.; Guan, Y.; Li, S.-L.; Wang, Q.; Ji, Y.; Zhu, D.; Hu, X.; Lin, C. Highly controllable ring-chain equilibrium in quadruply hydrogen bonded supramolecular polymers. Macromolecules 2012, 45, 9585-9594. [CrossRef] 
158. Zhang, Z.; Luo, Y.; Chen, J.; Dong, S.; Yu, Y.; Ma, Z.; Huang, F. Formation of Linear Supramolecular Polymers That Is Driven by $\mathrm{C}-\mathrm{H} \cdots \pi$ Interactions in Solution and in the Solid State. Angew. Chem. Int. Ed. 2011, 50, 1397-1401. [CrossRef]

159. Xiao, T.; Li, S.-L.; Zhang, Y.; Lin, C.; Hu, B.; Guan, X.; Yu, Y.; Jiang, J.; Wang, L. Novel self-assembled dynamic [2] catenanes interlocked by the quadruple hydrogen bonding ureidopyrimidinone motif. Chem. Sci. 2012, 3, 1417-1421. [CrossRef]

160. Rocchigiani, L.; Bellachioma, G.; Ciancaleoni, G.; Crocchianti, S.; Laganà, A.; Zuccaccia, C.; Zuccaccia, D.; Macchioni, A. AnionDependent Tendency of Di-Long-Chain Quaternary Ammonium Salts to Form Ion Quadruples and Higher Aggregates in Benzene. ChemPhysChem 2010, 11, 3243-3254. [CrossRef]

161. Zohourian, M.M.; Kabiri, K. Superabsorbent polymer materials: A review. Iran. Polym. J. 2008, 17, 447-451.

162. Kabiri, K.; Omidian, H.; Hashemi, S.; Zohuriaan-Mehr, M. Synthesis of fast-swelling superabsorbent hydrogels: Effect of crosslinker type and concentration on porosity and absorption rate. Eur. Polym. J. 2003, 39, 1341-1348. [CrossRef]

163. Nie, J.; Du, B.; Oppermann, W. Swelling, elasticity, and spatial inhomogeneity of poly (N-isopropylacrylamide)/clay nanocomposite hydrogels. Macromolecules 2005, 38, 5729-5736. [CrossRef]

164. Ganguly, S.; Das, N.C. Synthesis of Mussel Inspired Polydopamine Coated Halloysite Nanotubes Based Semi-IPN: An Approach to Fine Tuning in Drug Release and Mechanical Toughening. In Proceedings of the Macromolecular Symposia, December 2018; p. 1800076.

165. Haraguchi, K.; Takehisa, T. Nanocomposite hydrogels: A unique organic-inorganic network structure with extraordinary mechanical, optical, and swelling/de-swelling properties. Adv. Mater. 2002, 14, 1120-1124. [CrossRef]

166. Lee, W.F.; Chen, Y.C. Effect of bentonite on the physical properties and drug-release behavior of poly (AA-co-PEGMEA)/bentonite nanocomposite hydrogels for mucoadhesive. J. Appl. Polym. Sci. 2004, 91, 2934-2941. [CrossRef]

167. Lee, W.F.; Chen, Y.C. Effect of hydrotalcite on the physical properties and drug-release behavior of nanocomposite hydrogels based on poly [acrylic acid-co-poly (ethylene glycol) methyl ether acrylate] gels. J. Appl. Polym. Sci. 2004, 94, 692-699. [CrossRef]

168. Lee, W.F.; Fu, Y.T. Effect of montmorillonite on the swelling behavior and drug-release behavior of nanocomposite hydrogels. J. Appl. Polym. Sci. 2003, 89, 3652-3660. [CrossRef]

169. Molu, Z.B.; Seki, Y.; Yurdakoc, K. Preparation and characterization of poly (acrylic acid)/pillared clay superabsorbent composite. Polym. Bull. 2010, 64, 171-183. [CrossRef]

170. Li, A.; Wang, A. Synthesis and properties of clay-based superabsorbent composite. Eur. Polym. J. 2005, 41, 1630-1637. [CrossRef]

171. Harini, M.; Deshpande, A.P. Rheology of poly (sodium acrylate) hydrogels during cross-linking with and without cellulose microfibrils. J. Rheol. 2009, 53, 31-47. [CrossRef]

172. Ye, H.; Zhao, J.Q.; Zhang, Y.H. Novel degradable superabsorbent materials of silicate/acrylic-based polymer hybrids. J. Appl. Polym. Sci. 2004, 91, 936-940. [CrossRef]

173. Doniach, S. Changes in biomolecular conformation seen by small angle X-ray scattering. Chem. Rev. 2001, 101, 1763-1778. [CrossRef]

174. Das, N.C.; Sokol, P.E. Hybrid photovoltaic devices from regioregular polythiophene and ZnO nanoparticles composites. Renew. Energy 2010, 35, 2683-2688. [CrossRef]

175. Huang, B.; Hirst, A.R.; Smith, D.K.; Castelletto, V.; Hamley, I.W. A direct comparison of one-and two-component dendritic self-assembled materials: Elucidating molecular recognition pathways. J. Am. Chem. Soc. 2005, 127, 7130-7139. [CrossRef] [PubMed]

176. Ganguly, S.; Bhawal, P.; Choudhury, A.; Mondal, S.; Das, P.; Das, N.C. Preparation and properties of halloysite nanotubes/poly (ethylene methyl acrylate)-based nanocomposites by variation of mixing methods. Polym. Plast. Technol. Eng. 2018, 57, 997-1014. [CrossRef]

177. Bhawal, P.; Ganguly, S.; Das, T.K.; Mondal, S.; Das, N. Mechanically robust conductive carbon clusters confined ethylene methyl acrylate-based flexible composites for superior shielding effectiveness. Polym. Adv. Technol. 2018, 29, 95-110. [CrossRef]

178. Janicki, J. SAXS and WAXD real time studies on nanostructure of selected polymer materials. J. Alloy. Compd. 2004, 382, 61-67. [CrossRef]

179. Ganguly, S.; Mondal, S.; Das, P.; Bhawal, P.; Das, T.K.; Ghosh, S.; Remanan, S.; Das, N.C. An insight into the physico-mechanical signatures of silylated graphene oxide in poly (ethylene methyl acrylate) copolymeric thermoplastic matrix. Macromol. Res. 2019, 27, 268-281. [CrossRef]

180. Takeno, H.; Kimura, Y.; Nakamura, W. Mechanical, swelling, and structural properties of mechanically tough clay-sodium polyacrylate blend hydrogels. Gels 2017, 3, 10. [CrossRef]

181. Ganguly, S.; Maity, P.P.; Mondal, S.; Das, P.; Bhawal, P.; Dhara, S.; Das, N.C. Polysaccharide and poly (methacrylic acid) based biodegradable elastomeric biocompatible semi-IPN hydrogel for controlled drug delivery. Mater. Sci. Eng. C 2018, 92, 34-51. [CrossRef]

182. Ganguly, S.; Das, N.C. A comparison on self-seeding and isothermal crystallization of polyethylene in solution using small angle neutron scattering. Polymer 2015, 61, 192-197. [CrossRef]

183. Das, P.; Ganguly, S.; Bose, M.; Ray, D.; Ghosh, S.; Mondal, S.; Aswal, V.K.; Das, A.K.; Banerjee, S.; Das, N.C. Surface quaternized nanosensor as a one-arrow-two-hawks approach for fluorescence turn "on-off-on" bifunctional sensing and antibacterial activity. New J. Chem. 2019, 43, 6205-6219. [CrossRef]

184. Millon, L.E.; Nieh, M.-P.; Hutter, J.L.; Wan, W. SANS characterization of an anisotropic poly (vinyl alcohol) hydrogel with vascular applications. Macromolecules 2007, 40, 3655-3662. [CrossRef] 
185. Demirdöven, N.; Cheatum, C.M.; Chung, H.S.; Khalil, M.; Knoester, J.; Tokmakoff, A. Two-dimensional infrared spectroscopy of antiparallel $\beta$-sheet secondary structure. J. Am. Chem. Soc. 2004, 126, 7981-7990. [CrossRef]

186. Vivian, J.T.; Callis, P.R. Mechanisms of tryptophan fluorescence shifts in proteins. Biophys. J. 2001, 80, 2093-2109. [CrossRef]

187. Das, P.; Ganguly, S.; Agarwal, T.; Maity, P.; Ghosh, S.; Choudhary, S.; Gangopadhyay, S.; Maiti, T.K.; Dhara, S.; Banerjee, S. Heteroatom doped blue luminescent carbon dots as a nano-probe for targeted cell labeling and anticancer drug delivery vehicle. Mater. Chem. Phys. 2019, 237, 121860. [CrossRef]

188. Kim, H.J.; Lee, J.H.; Lee, M. Stimuli-responsive gels from reversible coordination polymers. Angew. Chem. 2005, 117, 5960-5964. [CrossRef]

189. Das, P.; Ganguly, S.; Mondal, S.; Ghorai, U.K.; Maity, P.P.; Choudhary, S.; Gangopadhyay, S.; Dhara, S.; Banerjee, S.; Das, N.C. Dual doped biocompatible multicolor luminescent carbon dots for bio labeling, UV-active marker and fluorescent polymer composite. Luminescence 2018, 33, 1136-1145. [CrossRef]

190. Rao, K.V.; Datta, K.; Eswaramoorthy, M.; George, S.J. Light-Harvesting Hybrid Hydrogels: Energy-Transfer-Induced Amplified Fluorescence in Noncovalently Assembled Chromophore-Organoclay Composites. Angew. Chem. Int. Ed. 2011, 50, 1179-1184. [CrossRef] [PubMed]

191. De Jong, K.P.; Geus, J.W. Carbon nanofibers: Catalytic synthesis and applications. Catal. Rev. 2000, 42, 481-510. [CrossRef]

192. Greiner, N.R.; Phillips, D.; Johnson, J.; Volk, F. Diamonds in detonation soot. Nature 1988, 333, 440-442. [CrossRef]

193. Kroto, H.W.; Heath, J.R.; O’Brien, S.C.; Curl, R.F.; Smalley, R.E. C 60: Buckminsterfullerene. Nature 1985, 318, 162-163. [CrossRef]

194. Ganguly, S.; Das, P.; Bose, M.; Das, T.K.; Mondal, S.; Das, A.K.; Das, N.C. Sonochemical green reduction to prepare Ag nanoparticles decorated graphene sheets for catalytic performance and antibacterial application. Ultrason. Sonochem. 2017, 39, 577-588. [CrossRef]

195. Das, T.K.; Bhawal, P.; Ganguly, S.; Mondal, S.; Das, N.C. A facile green synthesis of amino acid boosted Ag decorated reduced graphene oxide nanocomposites and its catalytic activity towards 4-nitrophenol reduction. Surf. Interfaces 2018, 13, 79-91. [CrossRef]

196. Mora, A.; Verma, P.; Kumar, S. Electrical conductivity of CNT/polymer composites: 3D printing, measurements and modeling. Compos. Part B Eng. 2020, 183, 107600. [CrossRef]

197. Bondon, N.; Raehm, L.; Charnay, C.; Boukherroub, R.; Durand, J.-O. Nanodiamonds for bioapplications, recent developments. J. Mater. Chem. B 2020, 8, 10878-10896. [CrossRef] [PubMed]

198. Jariwala, D.H.; Patel, D.; Wairkar, S. Surface functionalization of nanodiamonds for biomedical applications. Mater. Sci. Eng. C 2020, 113, 110996. [CrossRef]

199. Uthappa, U.; Arvind, O.; Sriram, G.; Losic, D.; Kigga, M.; Kurkuri, M.D. Nanodiamonds and their surface modification strategies for drug delivery applications. J. Drug Deliv. Sci. Technol. 2020, 101993. [CrossRef]

200. Kim, H.; Lee, S. Characterization of carbon nanofiber (CNF)/polymer composite coated on cotton fabrics prepared with various circuit patterns. Fash. Text. 2018, 5, 1-13. [CrossRef]

201. Saravanan, A.; Maruthapandi, M.; Das, P.; Ganguly, S.; Margel, S.; Luong, J.H.; Gedanken, A. Applications of N-doped carbon dots as antimicrobial agents, antibiotic carriers, and selective fluorescent probes for nitro explosives. ACS Appl. Bio Mater. 2020, 3 , 8023-8031. [CrossRef]

202. Das, P.; Maruthapandi, M.; Saravanan, A.; Natan, M.; Jacobi, G.; Banin, E.; Gedanken, A. Carbon dots for heavy-metal sensing, pH-sensitive cargo delivery, and antibacterial applications. ACS Appl. Nano Mater. 2020, 3, 11777-11790. [CrossRef] 